\title{
DIREITOS CULTURAIS, POLÍTICAS PÚBLICAS DE LEITURA, PROGRAMA CURITIBA LE: DIREITO E LITERATURA DE OUTRA PERSPECTIVA
}

\author{
LUCIANA ROCHA NARCISO ${ }^{1}$ \\ VERA KARAM DE CHUEIRI ${ }^{2}$
}

\begin{abstract}
RESUMo: Este artigo discute os direitos culturais e as políticas públicas de leitura e analisa o Programa Curitiba Lê. A pesquisa demonstra que o direito cultural à leitura é um direito humano fundamental para uma vida digna pautada nos princípios da igualdade e da liberdade. Para tanto, tem como objeto de estudo o Programa Curitiba Lê, instituído pela Prefeitura Municipal de Curitiba e executado pela Fundação Cultural de Curitiba com o objetivo de proporcionar à comunidade o acesso e a fruição à leitura e à literatura. A implementação do Programa Curitiba Lê possibilitou à Fundação Cultural de Curitiba empreender diversas ações com a finalidade de ampliar o interesse das pessoas pelos livros, para torná-las, de fato, leitoras, de maneira a possibilitar o acesso à leitura e o seu exercício. Através dos dados fornecidos pela FCC e das entrevistas realizadas com seus idealizadores e coordenadores, demonstra-se a importância da promoção de políticas públicas de cultura e o quão abrangente elas podem ser. O exercício dos direitos culturais, por meio de políticas públicas que viabilizem o seu acesso, exige um modelo de democracia dialógico e deliberativo. Para tanto, as teorias de Jürgen Habermas, Carlos Santiago Nino e Roberto Gargarella fundamentam a discussão e fornecem um modelo para a relação entre constitucionalismo e democracia que perpassa todo o trabalho.
\end{abstract}

Palavras-ChaVe: direitos culturais; direito à leitura; Programa Curitiba Lê; constitucionalismo e democracia.

1 Bacharel em Direito pela Pontifícia Universidade Católica do Paraná (PUCPR). Especialista em literatura pela Universidade Tecnológica Federal do Paraná (UTFPR). Mestre em Políticas Públicas pela Universidade Federal do Paraná (UFPR). Membro da comissão de Assuntos Culturais da OAB/PR, Coordenadora da Subcomissão de Literatura. Membro do Núcleo de Pesquisa Constitucionalismo e Democracia do Centro de Estudos da Constituição (CCONS) da UFPR. Professora da Faculdade IPPEO. Curitiba (PR), Brasil. CV Lattes: http://lattes.cnpq.br/2275934290822911. ORCID: https://orcid.org/o00o-0003-2644-7962. E-mail: lnarcisoadvocacia@gmail.com.

2 Mestre em Direito pela Universidade Federal de Santa Catarina (UFSC). Mestre em Filosofia pela New School for Social Research. Doutora em Filosofia pela New School for Social Research. Professora dos Programas de Graduação e Pós-Graduação em Direito da Faculdade de Direito da UFPR. Pesquisadora PQ2 do CNPq. Coordenadora do Núcleo de Constitucionalismo e Democracia do CCONS/PPGD/UFPR. Curitiba (PR), Brasil. CV Lattes: http://lattes.cnpq.br/6091643712340626 ORCID: https://orcid.org/o000-00017069-5272. E-mail: vkchueiri@gmail.com. 
Os verdadeiros analfabetos são os que aprenderam a ler e não leem.

Mario Quintana

Em princípio, só numa sociedade igualitária os produtos literários poderão circular sem barreiras, e neste domínio a situação é particularmente dramática em países como o Brasil, onde a maioria da população é analfabeta, ou quase, e vive em condições que não permitem a margem de lazer indispensável à leitura. [...] Pelo que sabemos, quando há um esforço real de igualitarização há aumento sensível do hábito de leitura, e portanto difusão crescente das obras.

Antonio Candido

\section{INTRODUÇÃO}

Este artigo tem como tema o exercício dos direitos culturais, mais especificamente o direito de acesso à leitura pela via das políticas públicas. Em conjunto com o direito de participar das conquistas científicas e tecnológicas e o direito moral e material à propriedade tecnológica e intelectual, os direitos culturais são fundamentais para a promoção da dignidade humana. Nesse sentido, o acesso à leitura, como direito cultural fundamental, alinha-se aos demais direitos dos cidadãos à uma vida digna em sentido amplo.

Parte-se do princípio de que a efetivação do acesso dos cidadãos aos direitos culturais torna-se possível mediante a criação de políticas públicas que o norteiem e lhe deem suporte. Tal consideração parece contrafactual, pois os direitos culturais deveriam ser acessíveis a todos e a todo tempo, entretanto, não o são. Seu exercício depende tanto da não ação do Estado, quando este, eventualmente, não cerceia a liberdade de manifestação cultural, como, e principalmente, da sua ação positiva, por meio de políticas públicas de cultura que viabilizem o acesso, o gozo e a fruição de tais direitos. 
Na sequência apresenta-se o problema que provocou a reflexão que orientou este artigo, bem como sua metodologia e objeto.

\subsection{Problema}

A premissa ora problematizada encontra-se expressa no artigo $215^{3}$ da Constituição Federal da República Federativa do Brasil de 1988 (CF/88) e deve ser compreendida em conjunto com o que dispõem os seus artigos 18 , caput, e 23, $\mathrm{V}^{4}$, quando determinam que devem agir conjuntamente a União, Estados e Municípios no intuito de proporcionar os meios de acesso à cultura aos cidadãos. Para tanto, parte da afirmativa de que a ação estatal, por meio das políticas públicas que resultam de decisões dos órgãos Executivo e Legislativo, deve ser pautada por uma agenda compartilhada com a sociedade civil.

Nesse sentido, se o exercício dos direitos culturais, por meio de políticas públicas, é para ser efetivo, ele exige um modelo de democracia dialógico e deliberativo. Daí a necessidade das instituições encarregadas de propor e executar as políticas públicas de cultura compartilharem sua proposição com a sociedade civil para que tal política pública seja eficaz, transformadora e permanente.

Sublinhe-se que público que qualifica a política refere-se tanto ao estatal / governamental quanto ao social / comunitário.

\subsection{Metodologia}

A pesquisa ora proposta é de caráter prescritivo quando parte do modelo democrático-constitucional de Estado para fundamentar políticas públicas e, também, de caráter descritivo, sendo qualitativa quanto à sua

3 Art. 215. O Estado garantirá a todos o pleno exercício dos direitos culturais e acesso às fontes da cultura nacional, e apoiará e incentivará a valorização e a difusão das manifestações culturais.

$\S 1^{\mathrm{O}} \mathrm{O}$ Estado protegerá as manifestações das culturas populares, indígenas e afrobrasileiras, e das de outros grupos participantes do processo civilizatório nacional.

$\S 2^{\circ}$ A lei disporá sobre a fixação de datas comemorativas de alta significação para os diferentes segmentos étnicos nacionais.

$\S 3^{\circ}$ A lei estabelecerá o Plano Nacional de Cultura, de duração plurianual, visando ao desenvolvimento cultural do País e à integração das ações do poder público que conduzem à: (Incluído pela Emenda Constitucional no 48, de 2005) [...]

4 Art. 18. A organização político-administrativa da República Federativa do Brasil compreende a União, os Estados, o Distrito Federal e os Municípios, todos autônomos, nos termos desta Constituição.

Art. 23. É competência comum da União, dos Estados, do Distrito Federal e dos Municípios:

$\mathrm{V}$ - proporcionar os meios de acesso à cultura, à educação, à ciência, à tecnologia, à pesquisa e à inovação; (Redação dada pela Emenda Constitucional no 85, de 2015) 
forma de abordagem, uma vez que o problema deste artigo é analisado por meio do estudo descritivo de caso do Programa Curitiba Lê. A análise feita sobre o Programa Curitiba Lê baseia-se nos dados disponibilizados pela Fundação Cultural de Curitiba (FCC), órgão responsável por sua formulação, implementação e execução. Os dados obtidos são apresentados em tabelas e gráficos seguidos das respectivas partes explicativas que sintetizam os resultados alcançados.

Considerando que a análise de tal modelo de ação estatal de cultura Programa Curitiba Lê - pressupõe determinado estado de coisas em relação à leitura e considerando a sua importância e necessidade para a efetivação dos direitos culturais e, consequentemente, para o fortalecimento do constitucionalismo democrático no Brasil, é trazido um diagnóstico da leitura no Brasil. Ou seja, tal diagnóstico fortalece as razões para a escolha do Programa Curitiba Lê como uma ação absolutamente relevante no sentido da democratização do direito cultural fundamental à leitura; com o intuito de demonstrar ao leitor por que ações dessa natureza são fundamentais para o desenvolvimento humano e social, para a consolidação do modelo de Estado social no constitucionalismo democrático, devendo, portanto, ser elevadas ao patamar de Políticas Públicas de Cultura por meio de legislação específica na esfera federativa correspondente.

Assim, o presente artigo focaliza a questão do acesso à produção, ao cultivo, à reprodução, fruição e compreensão do direito à cultura, por meio da viabilização do acesso à leitura e à criação literária como veículo de promoção da cidadania e de concretização do constitucionalismo e da democracia.

Este artigo apresenta a seguinte estrutura: (1) aspectos introdutórios que findam com o diagnóstico sobre a leitura no Brasil; (2) fundamentos que justificam a compreensão dos direitos culturais como direito humano a concretizar o princípio da dignidade; (3) implementação de políticas públicas no âmbito da cultura, bem como a importância do papel dos municípios no que tange à formulação dessas políticas culturais e a imprescindibilidade da participação popular nesse processo, desde a tomada de decisão até sua implementação propriamente dita; (4) análise de caso do PCL, por meio de avaliação documental e de banco de dados disponibilizados pela FCC. À tal análise agregam-se informações acerca das 
primeiras etapas do PCL, obtidas por meio de entrevistas com os agentes públicos que participaram da elaboração do PCL. Por fim, tecem-se algumas considerações com base nas premissas teóricas do trabalho e suas fundamentações, relacionando-as com a experiência do PCL.

Ressalte-se que a discussão feita neste artigo sobre o Programa Curitiba Lê utiliza os dados fornecidos pela FCC, entre os anos de 2010 e 2014. Ainda, a análise é delimitada ao espaço da cidade de Curitiba e no tempo indicado para que se possa realizar a pesquisa de maneira descritiva, analisando seus dados indutivamente, tendo todo o processo que envolve a existência desse programa e seu significado como focos integrantes dessa abordagem.

Com as informações obtidas junto à FCC estabelece-se, ainda, a relação existente entre o PCL e as diretrizes federais, estaduais e municipais no âmbito do livro e da leitura. Isso porque o artigo pretende também demonstrar que, quanto mais consonância houver entre as políticas culturais das três esferas governamentais, mais cidadãos são beneficiados e estimulados a exercer seu direito cultural, o qual é determinante para uma vida digna.

\subsection{Objeto da pesquisa}

O Programa Curitiba Lê, adiante também designado PCL, foi criado pela Fundação Cultural de Curitiba com o objetivo de proporcionar à comunidade o acesso e a fruição à leitura e à literatura, compreendendo o acesso e o exercício da leitura como direito cultural fundamental do qual os cidadãos curitibanos em específico, mas não só, são titulares.

A implementação do $P C L$ possibilitou à FCC empreender diversas ações com a finalidade de ampliar o interesse das pessoas pelos livros, para torná-las, de fato, leitoras, de maneira a possibilitar o acesso à leitura e o seu exercício como efetivação do direito fundamental à cultura. Consiste também, na efetivação, por meio da política pública de leitura, do que prescreve a norma dos artigos 215 e 216 da CF/88.

Construir e implementar uma política pública municipal para a área de literatura é o principal e mais geral objetivo do PCL desde sua proposição. Para tanto, a FCC decidiu criar espaços físicos de leitura, designando-os especialmente para esse fim, como também pautou o desenvolvimento e manutenção de políticas culturais de leitura como um 
serviço público prestado à comunidade, no intuito de garantir o direito de acesso à cultura.

O PCL criou 13 Casas da Leitura, conforme Quadro 1 e respectivo mapa (Figura 1).

Quadro 1 - Distribuição das casas de leitura do $P C L$ na cidade de Curitiba, por bairros Bondinho da Leitura: Bairro - Centro

Casa da Leitura Augusto Stresser: Bairro - São Lourenço

Casa da Leitura Dario Vellozo: Bairro - Largo da Ordem

Casa da Leitura Hilda Hilst: Bairro - Jardim das Américas

Casa da Leitura Jamil Snege: Bairro - Fazendinha

Casa da Leitura Manoel Carlos Karam: Bairro - Santo Inácio

Casa da Leitura Maria Nicolas: Bairro - Santa Felicidade

Casa da Leitura Miguel de Cervantes: Bairro - Bigorrilho

Casa da Leitura Nair de Macedo: Bairro - Guabirotuba

Casa da Leitura Osman Lins: Bairro - Capão Raso

Casa da Leitura Paulo Leminski: Bairro - Cidade Industrial de Curitiba (CIC)

Casa da Leitura Walmor Marcellino: Bairro - Sítio Cercado

Casa da Leitura Wilson Bueno: Bairro - Portão

Casa da Leitura Wilson Martins: Bairro - Boqueirão

Estação da Leitura: Bairro - Capão Raso (Terminal do Pinheirinho)

Fonte: IPPUC

Figura 1 - Delimitação das administrações regionais de Curitiba

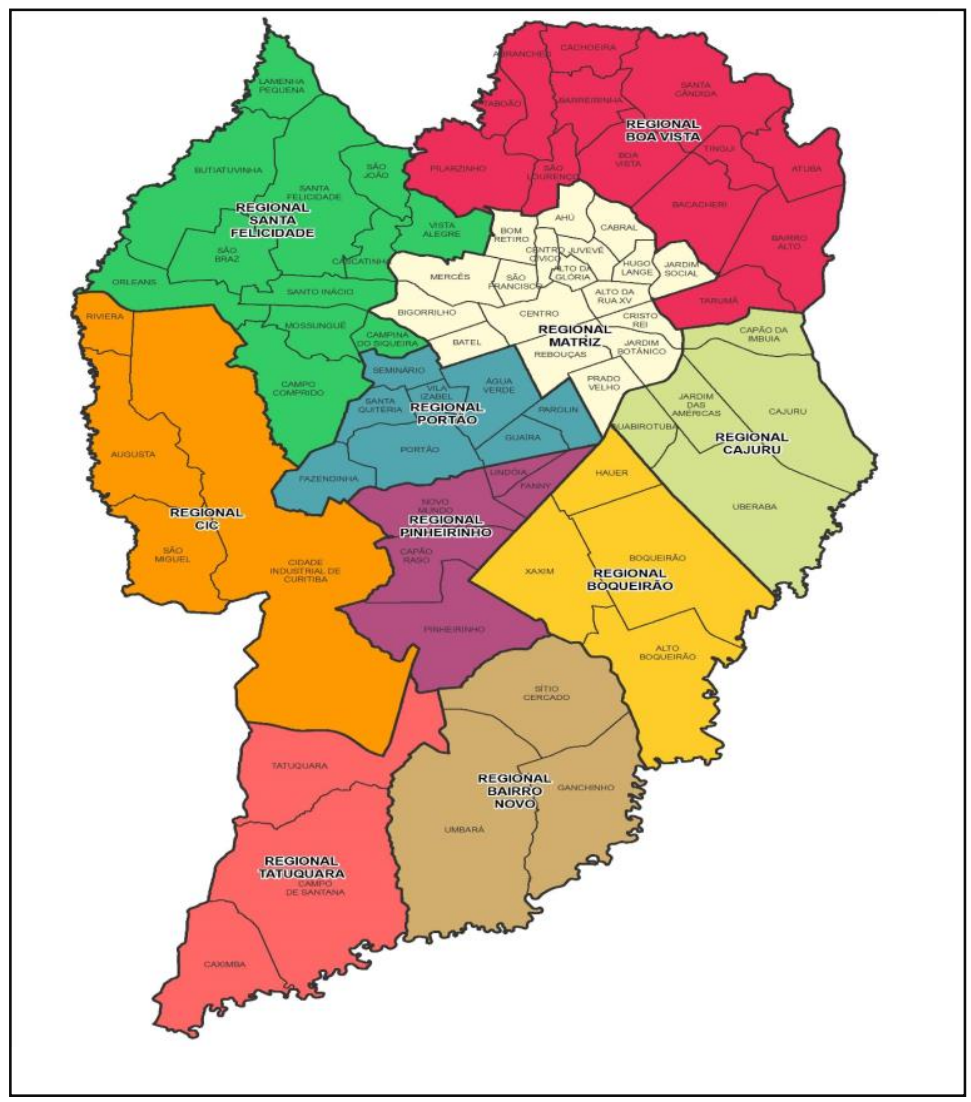

Fonte: IPPUC 
Ainda existem outros pontos, que são o Bondinho da Leitura, situado no calçadão para pedestres da Rua XV de Novembro, e a Estação da Leitura, pertencentes ao mesmo programa. A Estação da Leitura funciona dentro do Terminal de Ônibus do Bairro Pinheirinho como uma biblioteca.

\subsection{Diagnóstico da leitura no Brasil}

No que diz respeito ao acesso à leitura, o Brasil ainda carece da elaboração de políticas públicas de caráter contínuo e permanente que atendam a esse bem cultural tão importante para a formação do indivíduo. A leitura consiste num elemento importante para o desenvolvimento das potencialidades do ser humano. Por meio dela, o cidadão participa da sociedade, desenvolve espírito crítico, aprimora seu nível educacional, conhece outros valores e referências culturais.

Várias pesquisas, efetuadas nos últimos anos, buscaram apresentar dados mais nítidos do contexto em que se encontra a questão da leitura e do livro no País, possibilitando maior consciência das dificuldades que atingem o setor e proporcionando dados concretos para que se possa melhorar a situação.

Muitas dessas pesquisas são utilizadas pelo próprio Governo Federal quando procura arrolar os dados sobre a leitura no país, como se pode observar no Caderno do Plano Nacional do Livro e da Leitura (PNLL), no qual o governo considerou que os índices demonstrados por essas pesquisas justificavam a edição do Caderno/Plano.

$\mathrm{Na}$ edição atualizada e revisada de 2014 do Caderno do PNLL, editado pelo MINC (Ministério da Cultura), a leitura é considerada um elemento fundamental

para a construção das sociedades democráticas baseadas na diversidade, na pluralidade e no exercício da cidadania; é direito de todos, constituindo condição necessária para que cada indivíduo possa exercer seus direitos fundamentais, viver uma vida digna e contribuir na construção de uma sociedade mais justa (Brasil, 2014, p. 20).

Alguns dados, abaixo elencados, indicando a situação da cultura e da leitura no Brasil, sugerem que políticas públicas alinhadas ao PNLL devem ser instituídas com caráter de permanência e continuidade pelos três níveis do Poder Executivo (federal, estadual e municipal), com o objetivo de aumentar o acesso dos brasileiros a esse direito cultural; o que certamente 
elevará o número de leitores no país. Pode-se observar, também, pela pesquisa exposta no item 4.2, o valor investido pelos entes governamentais no setor da cultura.

A coletânea de dados a seguir apresentada, ainda que signifique apenas um esboço da questão da leitura no Brasil, oferece elementos para contextualizar e justificar a proposição de políticas públicas de cultura que possibilitem o acesso aos direitos culturais - e no caso do presente estudo, o acesso ao direito à leitura por parte de todos os cidadãos brasileiros. $\mathrm{E}$ ainda, os resultados apontam para o fato, no item 4.2, de que as três instâncias do Governo - Federal, Estadual e Municipal - devem aumentar o investimento no setor.

1.4.1 Terceira edição da pesquisa do IBOPE e Instituto Pro Livro: retratos da leitura no Brasil 3

Pesquisa efetuada entre junho e julho de 2011 pelo Instituto Pró Livro - Retratos da Leitura no Brasil 3, através do IBOPE Inteligência, entrevistou mais de 5.000 pessoas em 315 municípios do Brasil (Failla, 2012).

A definição da amostra considerou a distribuição da população de mais de 5 anos nas 5 regiões brasileiras, conforme os dados da Pesquisa Nacional por Amostra de Domicílios - PNAD de 2009. Para verificar os índices de leitura, foi efetuado um detalhamento sobre a leitura nos últimos três meses, segundo diferentes perfis da amostra e conceitos. Entre outros objetivos específicos, essa pesquisa apresenta os índices de leitura do brasileiro.

O Instituto Pró-Livro - IPL é uma associação sem fins lucrativos criada em 2006, pelas entidades do livro - Abrelivros (Associação Brasileira de Livros), Câmara Brasileira do Livro - CBL e Sindicato Nacional dos Editores de Livros - SNEL, com o objetivo principal de fomento à leitura e à difusão do livro. É mantido com recursos e contribuições dessas entidades.

A pesquisa foi a terceira do gênero realizada no país e considerou que leitor é quem leu pelo menos um livro nos últimos três meses.

Os resultados da pesquisa constataram uma redução no número de leitores do país: em 2011 eram 88,2 milhões de leitores, o que corresponde a 50\% da população; sendo que em 2007 a mesma pesquisa indicou que 
$55 \%$ da população era leitora. Houve, portanto, uma diminuição de 7,4 milhões de leitores no intervalo de 2007 para 2011.

Os motivos relatados foram, primeiramente, falta de interesse $(78 \%$ dos entrevistados) e, após, falta de tempo (50\% dos entrevistados). O preço dos livros ficou em $13^{\circ}$ lugar como razão para se ler menos, com $2 \%$ dos entrevistados.

Também foi apurado que $85 \%$ das pessoas preferem assistir à televisão em seu tempo livre; e 52\%, ouvir música ou rádio. A opção pela leitura fica em $7^{\circ}$ colocação, com $28 \%$.

Ao final, a pesquisa indicou que o brasileiro lê uma média de quatro livros por ano, sendo dois por encomenda da escola e 1,85, por opção. Assim sendo, a pesquisa apresenta, com base nesses dados, que 50\% da população brasileira não é leitora e que, entre a população leitora, a média de livros lidos é de 1,85 livros ao ano.

1.4.2 Pesquisa do IBGE (Instituto Brasileiro de Geografia e Estatísticas) e SNIIC (Sistema Nacional de Informações e Indicadores Culturais)

O Sistema Nacional de Informações e Indicadores Culturais (SNIIC), integrante do MINC, tem o objetivo de subsidiar as ações culturais públicas e privadas. Reúne e disponibiliza via web dados e informações culturais envolvendo pesquisas e estatísticas, cadastro cultural e fomento à cultura. Tem como tarefa cadastrar, organizar, sistematizar e difundir informações para a construção de indicadores relacionados ao setor cultural brasileiro, funcionando como um mapeamento on line, dinâmico e com a responsabilidade da informação assumida pelo próprio usuário.

No que diz respeito aos investimentos governamentais para a área da cultura, o SNIIC, realizado pelo IBGE em parceria com o Ministério da Cultura para avaliar os dados referentes ao período de 2007 a 2010, constatou que os gastos governamentais com a cultura nas esferas federal, estadual e municipal totalizaram $0,3 \%$ do total das despesas consolidadas da administração pública, por ano, do período analisado.

No tangente à participação dos municípios, a pesquisa indicou que houve redução de 49,0\% em 2007 (R 2,2 bilhões) para 44,5\% em 2010 (R \$ 3,2 bilhões) nos investimentos em ações culturais, porém, ainda são os municípios os principais entes governamentais no que diz respeito ao total de gastos públicos com cultura. 
1.4.3 Pesquisa do PISA (Programa Internacional de Avaliação dos Estudantes)

O Brasil submeteu-se à última avaliação efetuada pelo PISA (Programa Internacional de Avaliação dos Estudantes), prova aplicada pela Organização para Cooperação e Desenvolvimento Econômico (OCDE) de três em três anos, para alunos que se encontram na faixa etária de quinze anos.

A Organização de Cooperação e de Desenvolvimento Econômico, criada em 1947, é uma entidade internacional com sede na França, composta por 34 países e tem como objetivo a promoção de políticas que auxiliem o desenvolvimento econômico e o bem-estar social de pessoas por todo o mundo.

O PISA foi desenvolvido pela OCDE para avaliar estudantes matriculados a partir do sétimo ano de estudo, que estão próximos de concluir sua educação básica e já devem possuir, portanto, os requisitos educacionais básicos nas áreas da leitura, matemática e ciências. A avaliação é trienal, sendo que a cada edição o foco está centrado em uma área principal a ser avaliada.

No que diz respeito à leitura, foram incluídas a avaliação de leitura eletrônica e a elaboração de construções relacionadas ao envolvimento com leitura e cognição. Para a prova de 2012 adotou-se o entendimento de que "Letramento em leitura é a capacidade de compreender, utilizar, refletir e envolver-se com textos escritos, com a função de alcançar uma meta, desenvolver seu conhecimento e seu potencial, e participar da sociedade" (OECD, 2013). Dos 65 países analisados, o Brasil ficou em $55^{\circ}$ lugar em leitura.

Os indicadores ora apresentados apontam que os índices de leitura no Brasil podem ser considerados, ainda, passíveis de serem incrementados, motivo pelo qual pretende-se, neste estudo, demonstrar a importância da implementação de Políticas Públicas de Cultura como a que tem sido realizada por meio do PCL. O conjunto de dados aqui elencado, embora constitua somente um esboço da situação da leitura, do livro, da literatura e das bibliotecas no Brasil, possui elementos suficientes para contextualizar e justificar a proposição de um estudo como este.

Entretanto, a política pública de leitura na perspectiva que defendemos não tem um caráter meramente utilitarista no sentido de maximizar o bem-estar geral e a felicidade de toda comunidade. Antes, ela 
refere-se à efetivação de um direito humano cultural fundamental do qual todos os cidadãos de determinada comunidade política são titulares. No Estado brasileiro, tal sentido foi constitucionalizado de maneira que a $\mathrm{CF} / 88$ prescreve o direito à cultura, a garantia de seu exercício e das suas fontes, bem como as formas de sua efetivação (artigos 215, 216, combinados com o artigo 23 da $\mathrm{CF} / 88$ ).

\section{DIREITOS CULTURAIS COMO DIREITOS FUNDAMENTAIS NO ESTADO DEMOCRÁTICO- CONSTITUCIONAL}

Os direitos culturais são direitos humanos fundamentais a concretizar o princípio da dignidade humana. Daí o caráter central da Constituição e de suas normas de direitos fundamentais conforme o sentido que lhes tem dado o Estado Democrático Constitucional. Tais normas se apresentam como princípios ou políticas públicas que, vertidos no código do direito, dão a direção para as decisões executivas e legislativas e, respectivamente, para as decisões em matéria de política cultural.

Considerando o fato do Brasil ser signatário de diversos documentos internacionais como tratados, pactos, cartas, convenções e declarações que versam sobre a proteção e o acesso aos direitos culturais, importa destacar também essa fonte normativa que incide, de forma subsidiária, na proteção e na prestação dos direitos humanos fundamentais.

A constitucionalização dos direitos fundamentais culturais se deu, sobretudo, a partir da metade do século XX, fazendo com que sua efetivação, seja mediante a implementação de políticas públicas e sociais, seja pela elaboração de leis infraconstitucionais, torne-se indispensável.

$\mathrm{O}$ direito de acesso aos Direitos Culturais, atrelado à ideia de princípio fundamental, está contido na $\mathrm{CF} / 88$ por ser considerado um direito imprescindível para a promoção da dignidade humana e para o desenvolvimento do indivíduo em sociedade. Mas, o que são exatamente os Direitos Culturais?

Primeiramente os Direitos Culturais consistem em direitos humanos fundamentais, e como tal congregam uma série de direitos objetivos e subjetivos. Devido a abrangência de concepções que essa espécie de direitos abarca, o conceito de Direitos Culturais não se exaure numa frase ou num 
ponto de vista. Algumas definições, entretanto, auxiliam na compreensão acerca do que vêm a ser estes direitos.

Para Francisco Humberto Cunha Filho (2000, p. 41),

Direitos Culturais são aqueles afetos às artes, à memória coletiva e ao fluxo de saberes, que asseguram a seus titulares o conhecimento e uso do passado, interferência ativa no presente e possibilidade de previsão e decisão de opções referentes ao futuro, visando sempre à dignidade da pessoa humana.

Bisch e Bidault (2014, p. 31) afirmam que

Direitos Culturais designam direitos e liberdades que tem uma pessoa, isoladamente ou em grupo, de escolher e expressar sua identidade e de ter acesso às referências culturais, bem como aos recursos que sejam necessários a seu processo de identificação, de comunicação e de criação.

Ainda segundo esses autores franceses: "Esses direitos protegem a capacidade do sujeito de se ligar aos outros graças aos saberes contidos nas obras (coisas e instituições) dentro das comunidades onde ele evolui” (Meyer-Bisch; Bidault, 2014 p. 57).

A efetivação e a concretização dos Direitos Culturais estão relacionadas à questão da participação e do acesso à produção científica, tecnológica, artística, literária, e ao direito a desfrutar dos avanços e benefícios conquistados mediante essa produção5.

\subsection{Direitos culturais e a ideia de cultura}

Ressalta-se que, dada a abrangência dos direitos culturais, não é tarefa fácil conceituá-los devido, muito em parte, à complexidade que envolve o conceito de cultura. Além disso, devem ser levadas em conta a proximidade e a transversalidade existentes entre os direitos culturais e outros direitos fundamentais, como, por exemplo, se verifica com o direito à educação, com o direito à liberdade de expressão, à livre associação, à liberdade de opção religiosa, à livre expressão artística, ao direito de ir e vir, dentre outros tantos. Nesse sentido, afirma Farida Shaheed (2011, p. 20):

Os direitos culturais constituem uma área de desafio justamente porque estão ligados a uma vasta gama de questões que variam da criatividade e expressão artísticas em diversas formas materiais e não materiais a questões de língua, informação e comunicação; educação;

5 Conforme anteriormente indicado, observar o que dispõe o artigo 215 da CF88. 
identidades múltiplas de indivíduos no contexto de comunidades diversas múltiplas e inconstantes; desenvolvimento de visões de mundo específicas e a busca de modos específicos de vida; participação na vida cultural, acesso e contribuição a ela; bem como práticas culturais e acesso ao patrimônio cultural tangível e intangível.

Humberto Cunha Filho (2000, p. 28) opta por definir cultura como a produção humana vinculada ao ideal de aprimoramento, visando à dignidade da espécie como um todo e de cada um dos indivíduos. Adverte o autor que a subjetividade dos termos da definição passa a ganhar forma concreta segundo a observação de cada ordenamento jurídico.

Todavia, para este estudo, interessa definir o que é cultura para a política cultural. E, nesse sentido, a definição de Teixeira Coelho parece se adequar ao princípio da democracia dialógica, que possibilitará que cada grupo social, dotado de suas peculiaridades sociais, econômicas, regionais e culturais, exponha suas tendências, talentos, necessidades e anseios relacionados ao campo cultural:

O melhor resumo da ideia de cultura (e que poucas políticas culturais se dispõem a aceitar) é aquele que apresenta a cultura como uma longa conversa [...] entre tudo o que é cultura, entre todos os que movem a cultura. [...] A melhor ideia de liberdade e cultura é essa ideia de conversa. Essa, na verdade, é a melhor ideia de liberdade (Coelho, 2012, p. 118).

Se a melhor ideia de cultura é a ideia de conversa, mais uma vez se pode afirmar que a efetivação do acesso aos Direitos Culturais num Estado Constitucional Democrático está diretamente relacionada à questão da participação popular no momento das decisões relacionadas às Políticas Públicas de acesso à Cultura. E essa questão não se realiza se os representantes do poder público não compartilharem com o povo a tomada de decisões que lhes afetarão. A maneira de saber quais são os anseios populares e necessidades é abrindo espaços para a participação onde a população possa discutir e delibera.

É importante destacar o papel tridimensional da cultura insculpido na CF/88 - simbólico, cidadão e econômico - que faz com que os direitos culturais, sua proteção e acesso, sejam considerados fundamentais ao desenvolvimento de qualquer indivíduo, comunidade ou país. 
A dimensão cidadã caracteriza-se quando o indivíduo participa, do processo de escolha e implementação das ações culturais, com o Poder Público, assegurando o pleno exercício dos direitos culturais a todos os cidadãos indistintamente e possibilitando o acesso à cultura mediante o estímulo à criação livre, a democratização das condições para produção cultural, formação, difusão, promoção das possibilidades de fruição e a livre circulação de valores e bens culturais.

A dimensão simbólica vem a ser o conjunto dos bens de natureza material e imaterial que constituem o patrimônio cultural, que envolve todos os modos de viver, fazer e criar dos diferentes grupos formadores da sociedade, conforme o artigo 216 da CF/88. O Poder Público tem o dever de promover e proteger as várias formas de criação simbólica que se traduzem em modos de vida, práticas, valores, crenças e rituais, que constituem as identidades dos indivíduos.

Daí porque as políticas públicas culturais devem entender e proteger os bens culturais como sendo portadores de conceitos, valores, ideias e sentidos que formam a identidade e a diversidade cultural do povo brasileiro e, consequentemente, do país. Uma vez anulada a cultura de um povo, na sua dimensão simbólica, anulada estará a identidade desse povo e suas maneiras genuínas (originais) de se expressar, pensar, sentir e viver.

A dimensão econômica deflagra-se quando as políticas públicas são pensadas para a transformação social e o desenvolvimento local por meio da cultura, gerando trabalho, profissionalização e, consequentemente, renda para a comunidade, bem como incrementando a economia local e melhorando a vida dos seus cidadãos.

O benefício econômico pode se estender aos estados, às regiões e a todo o território nacional, se cada esfera do governo atuar em conformidade com a CF/88 e em consonância cada uma para com as demais. Isso envolve a participação popular no processo de implementação de políticas públicas de cultura, pois somente valorizando os cidadãos e suas vocações é que se poderá atingir um grau de desenvolvimento social e cultural que proporcione a vivência plena da cidadania; mediante o respeito aos princípios da dignidade humana e da igualdade. 


\subsection{Políticas públicas de cultura}

As Políticas Públicas de Cultura reivindicam a participação popular no processo de sua concretização. Daí a preocupação com a descentralização e democratização da gestão e das políticas públicas, assim como com a abertura de espaços institucionais para a manifestação de grupos e membros da sociedade, novas formas de participação se tornam possíveis no cenário político da cultura.

Por questões geográficas, econômicas, históricas, políticas, climáticas, entre outras, o Brasil possui enorme diversidade cultural distribuída por seu vasto território, o que imprime marcantes distinções entre as cinco regiões, os 27 estados e os milhares de municípios brasileiros entre si. A $\mathrm{CF} / 88$, ao propor uma descentralização dos assuntos culturais delegando responsabilidades e prerrogativas aos Estados e aos Municípios, possibilita, mais uma vez, que a população afetada pelas decisões seja ouvida e possa ser atendida no momento da elaboração e efetivação das políticas públicas. Deve-se considerar que as características regionais e populacionais demandam mais especificidade e mais respeito às tradições e particularidades de cada povo e de cada local, devendo este povo ser ouvido.

Mais um motivo torna indispensável a participação popular nas questões afetas à cultura: o Brasil é um país marcado pela diversidade, assim como pela desigualdade social.

Não se pode acreditar que uma norma sobre cultura emanada pelo Governo Federal possa atender satisfatoriamente a todas as regiões, estados e municípios brasileiros da mesma maneira; e, assim, o artigo 18 da CF/88 consagra, novamente, a necessidade da aproximação entre poder público e comunidade.

A CF/88 adota uma perspectiva participativa na área cultural, abrindo espaço para a sociedade civil dialogar com a administração pública do país em seus três níveis na Federação. Ainda, a CF/88 impôs ao Estado a tarefa de viabilizar o acesso do cidadão aos bens e direitos fundamentais por meio de políticas públicas, vinculando, dessa maneira, os representantes dos três poderes a tal obrigação. Além disso, determinou a criação de espaços institucionais de discussão e deliberação em questões afeitas a todos os cidadãos, como as de cultura. 
A criação de conselhos e conferências de políticas públicas previstos pela $\mathrm{CF} / 88$, por exemplo, foi inserida no texto constitucional com o intuito de proporcionar a participação da sociedade na elaboração e na gestão de políticas públicas.

As demandas, dessa forma, passam a ser influenciadas por uma agenda que se origina na sociedade civil por meio da participação da sociedade, que não é composta somente por indivíduos, mas também pela iniciativa privada, instituições e organizações de um modo geral. Somente dando voz a todos esses entes sociais é que se pode ampliar e efetivar direitos de cidadania originados das lutas sociais pela democracia, que devem ser reconhecidos e protegidos institucionalmente.

Outra inovação da $\mathrm{CF} / 88$, com relação às Políticas Públicas de Cultura, é que o artigo 23 modificou outra prática que perdurou até o final da ditadura militar, em que os estados e municípios ficavam completamente afastados das prerrogativas concernentes à instituição de políticas públicas de cultura. A CF/88 no artigo 23 impõe a repartição de receitas e de responsabilidades entre União, Estados e Municípios, visando a aumentar os investimentos na área de cultura e criando também os mecanismos para efetuar as transferências de recursos previstos para políticas culturais.

Com isso, busca-se a descentralização da administração da área cultural no país, o que possibilita maior respeito e atenção às tradições culturais regionais, suas peculiaridades, urgências e possibilidades, como se verá abaixo.

No que tange especificamente à questão da cultura, o referido artigo determina que é competência comum da União, dos Estados, do Distrito Federal e dos Municípios proteger os documentos, as obras e outros bens de valor histórico, artístico e cultural, os monumentos, as paisagens naturais notáveis e os sítios arqueológicos; impedir a evasão, a destruição e a descaracterização de obras de arte e de outros bens de valor histórico, artístico ou cultural; proporcionar os meios de acesso à cultura, à educação e à ciência; e, ainda, proporcionar os meios de acesso à cultura, à educação, à ciência, à tecnologia, à pesquisa e à inovação. (Redação dada pela Emenda Constitucional no 85, de 2015). 
Os três níveis de governo são, dessa forma, considerados igualmente competentes e, mais, coobrigados a instituir políticas públicas que atendam aos dispositivos constitucionais. A $\mathrm{CF} / 88$ introduziu alterações no federalismo brasileiro quando autoriza a transferência de recursos e de encargos para os estados e municípios, condicionando tais repasses à ação positiva desses entes. De toda forma, as três esferas de governo, no Brasil, "se demonstraram interdependentes de modo que as linhas divisórias entre elas são difíceis de serem definidas" (SEBRAE, 2005, p. 26).

É fato que o Município passou a ter, a partir da $\mathrm{CF} / 88$, seu papel redefinido e leque de competências ampliado já que adquiriu o status de ente federativo, assim como os Estados e a união federal.

Em termos políticos e administrativos, os municípios, com a promulgação da $\mathrm{CF} / 88$, passaram a ter maior autonomia. Tal situação favoreceu a participação popular, uma vez que os administradores públicos municipais possuem maior proximidade física da população e vice-versa, e, ainda, cada município pode ter suas leis municipais independentemente de aprovação estadual ou federal, o que permite que cada qual elabore leis que favoreçam as vocações regionais de acordo com o perfil, potencialidades e necessidades de sua população.

O poder local tem grande influência na questão do desenvolvimento cultural, assumindo o município importante papel na consolidação de uma perspectiva de desenvolvimento nacional. O município é que se encontra mais próximo ao povo e é, portanto, detentor de maiores condições para atender às demandas populares, inclusive na esfera da cultura.

Teixeira Coelho, na introdução da obra intitulada $A$ cultura pela cidade, afirma que "A cidade é a primeira e decisiva esfera cultural do ser humano. E para realçar ainda mais seu papel está o fato de que hoje, pela primeira vez na história da humanidade, mais da metade da população mundial vive em cidades" (Coelho, 2008, p. 9).

Acredita-se que o município é o palco ideal onde devem figurar os acontecimentos culturais do país, pois no âmbito municipal o contato com o público é mais acessível; como foi demonstrado acima, se levarmos em conta as diferenças e peculiaridades existentes entre as regiões brasileiras e consequentemente entre seus municípios (densidade demográfica, fontes de renda da população, clima, geografia, renda média da população, grau de 
industrialização, proximidade do campo, entre outras diferenças), essa afirmativa revela-se ainda mais adequada ao caso do Brasil.

Nesse sentido, o município figura como a unidade de governo mais apta a possibilitar a abertura de espaços onde o povo possa se manifestar. Ao município cabe, portanto, abrir esses espaços, como veículo para consolidação da democracia, que deve ser cumprida para que haja possibilidade de efetivação dos direitos fundamentais.

O inglês Charles Landry, que cunhou o termo "cidade criativa", sustenta que a contribuição da cultura está na sua vitalidade, na qualidade de participação cultural, na construção do diálogo entre seus habitantes e na promoção da diversidade, construindo lugares onde as pessoas querem morar, trabalhar e se divertir. No livro The Creative City (A cidade criativa) de 1995, Landry e Bianchini abordam temas relevantes e inovadores como a importância do patrimônio cultural para a economia, ressaltando o valor cidadão da cultura que proporciona, entre outros benefícios, trabalho, remuneração e, ainda, fortalecimento da identidade de um povo.

Em outra obra, The Creative City: A Toolkit for Urban Innovators (Cidade criativa: um kit de ferramentas para inovadores urbanos), Landry defende que é nas especificidades de cada lugar que as cidades ressaltam suas potencialidades, o que o autor denomina ativos urbano-econômicos, postulando que mediante a cultura e a criatividade se pode "tornar uma fraqueza numa força”, pois se utiliza o potencial local não aproveitado em benefício urbano. Para o autor, cada cidade tem a potencialidade de ser um centro global de algo, se persistentemente se esforçar em olhar para si própria e para o potencial dos seus recursos (Landry, 2008, p. 8).

\subsection{Participação popular e políticas públicas}

No que diz respeito à democracia, que somente se concretiza por meio da participação de membros da sociedade civil no processo de deliberação política e implementação de políticas públicas, este artigo o entende como um instrumento de fortalecimento do próprio constitucionalismo. O espaço para manifestação popular deve ser interpretado, no Estado democrático, como o pressuposto maior para a atuação política e regulamentadora, para que as normas possuam legitimidade moral, além da imperatividade inerente às leis. 
Habermas, ao defender a comunicação (ação comunicativa) entre todos os cidadãos e o respeito à opinião de todos para que se desenvolvam ações políticas satisfatórias à população, propõe que ao se "adotar o enfoque performativo de um falante que deseja entender-se com uma segunda pessoa sobre algo no mundo, as energias de ligação da linguagem podem ser mobilizadas para a coordenação de planos de ação" (Habermas, 2003. p. 36.)

Para Habermas, toda ordem jurídica também é decorrente de uma forma de vida particular e não apenas o reflexo do teor universal dos direitos fundamentais. Por isso, o autor postula que "a substância dos direitos humanos insere-se, então, nas condições formais para a institucionalização jurídica desse tipo de formação discursiva da opinião e da vontade, na qual a soberania do povo assume figura jurídica" (Habermas, 2003. p. 207).

A esfera pública, para esse autor, deve ser constituída por espaços que dão materialidade à formação discursiva popular. Esse espaço se encontra presente em vários tipos de instituições, tais como: associações, universidades, partidos políticos, imprensa, sindicatos e organizações não governamentais.

Souza Neto assinala que,

assim estruturado, o modelo de Habermas revela que a legitimidade das decisões estatais depende de dois fatores coordenados: a institucionalização jurídica dos procedimentos de legiferação e a abertura do sistema estatal aos influxos comunicativos que advém do espaço público (2006, p. 155).

Nesse diapasão, Carlos Santiago Nino postula que o princípio da ética discursiva, pilar da democracia deliberativa, somente acata a validade de normas que alcançarem, ou que possam alcançar, a aprovação das pessoas afetadas em sua condição de participantes do discurso concreto (Nino, 1999, p. 159).

Ademais, Nino ressalta que a imparcialidade é requisito fundamental para a busca da solução mais adequada por meio de práticas discursivas coletivas ou individuais, pois afirma que, se os indivíduos potencialmente afetados por uma decisão tiverem participado da discussão sobre o tema em condições de igualdade, a decisão tomada será imparcial e moralmente 
correta, sempre que todos a aceitarem livremente e sem coerção (Nino, 1999, p. 166).

Ainda sobre a importância da participação popular para concretização da democracia, Battini ensina que "participar é exercitar a democracia. Isso pressupõe o pluralismo de ideias e práticas, a convivência de grupos de interesses diversos que tem contradições quanto aos objetivos e aos meios de consegui-los" (Battini, 1993, p. 31).

A participação popular em todas as fases das decisões políticas, além de ser um pressuposto para que o Estado Constitucional seja democrático, é um princípio fundamental que norteia a $\mathrm{CF} / 88$ e que deve reger todas as políticas públicas e tomadas de decisão em razão do caráter vinculante da CF.

O diálogo estabelecido entre sociedade civil e sociedade política deve servir de base para a definição das prioridades na elaboração e consecução das políticas públicas de cultura. Assim, a participação da sociedade deve ser encarada como uma intervenção social planejada. Somente assim passa a existir uma cooperação permanente entre governos e cidadãos e, consequentemente, as políticas públicas culturais atenderão, enfim, às necessidades da população proporcionando pleno desenvolvimento individual e coletivo no campo cultural.

A participação popular nas discussões e decisões culturais que afetam a comunidade levanta a questão da igualdade. Vale dizer, numa sociedade marcada por acentuada desigualdade e pela desigual distribuição de recursos, como é o caso da sociedade brasileira, deve-se atentar ao fato de que existe enorme possibilidade de que as decisões acerca das questões públicas da comunidade sejam em benefício de uma parcela minoritária e privilegiada da sociedade, ressaltando-se nesse ponto a distância que caracteriza essas pessoas da população em geral.

Acerca disso, Gargarella postula que, mesmo que tal distância fosse, de alguma maneira, diminuída, ainda assim haveria uma falha no processo democrático, visto que as questões públicas mais relevantes continuariam a ser decididas por poucos e não por muitos (Gargarella, 2008, p. 261).

Tal proposta de igualdade na participação e nas decisões dos assuntos que afetam à sociedade busca "reinstalar uma dimensão igualitária que se perde quando a vida coletiva fica sujeita ao resultado do incentivo e de 
iniciativas de uma minoria poderosa" (Gargarella, 2008, p. 262). Nesse viés, em uma sociedade igualitária (ou verdadeiramente democrática), as possibilidades de reunião, discussão e decisão coletivas sobre as questões públicas e coletivas mais relevantes devem se fazer efetivas e possíveis. É assim que a vida pública se torna o resultado do acordo celebrado entre iguais, independentemente dos recursos econômicos ou da capacidade de influência política de que se disponha.

Postular por uma ideia robusta de igualdade é reconhecer a vontade pública, que somente pode se manifestar pacificamente com um processo de discussão e tomada de decisão coletivas, o que demanda a difusão de informação e a confrontação de divergentes pontos de vista a respeito de alguns assuntos.

Seguindo o entendimento de Gargarella, deve-se ter presente que, em países como o Brasil - em que grande parte da população ainda vive em condições precárias (para não dizer condições de pobreza e miséria extremas), tendo seus direitos culturais (entre outros) violados cotidianamente por ações ou, principalmente, por omissões, sem acesso sequer à educação formal e à leitura, uma significativa parcela fica automaticamente excluída desse processo de discussão e decisão da vida pública.

O autor menciona a questão histórica de países onde a exclusão da comunidade dos assuntos que a afetam foi política e socialmente construída - não configurando um resultado do acaso ou mero acidente inesperado. A injustiça e a desigualdade, motivadas por iniciativas pessoais, têm como pressuposto a existência de relações assimétricas, em que não está presente igual respeito e consideração ao outro. Gargarella faz alusão à situação de desvantagem da qual, desde os tempos da colonização, partiram os índios, negros, imigrantes pobres e trabalhadores, desvantagem oriunda de uma postura de renegação que indivíduos privilegiados e o próprio Estado lhes impuseram historicamente (Gargarella, 2008, p. 269-270).

Exigir que essas pessoas se libertem, por conta própria, da situação de inferioridade social (ou cultural) em que se encontram é, no mínimo, assumir uma postura passivamente condizente com a conduta da classe que as oprime. 
Para que a igualdade de participação seja materializada, a sociedade, em sua totalidade, deve procurar tornar efetivas as possibilidades de reunião, discussão e decisão coletivas sobre os assuntos públicos e coletivos mais relevantes que afetam essa sociedade. Gargarella adverte, contudo, que tal procedimento não implica ratificar o ditado "a voz do povo é a voz de Deus" ou, então, que toda matéria de interesse público deva ser resolvida coletivamente mediante a intervenção de todos os membros da sociedade ou por meio de reuniões de milhões de pessoas para discutir um tema. Pelo contrário, a ideia é de que a vontade e as necessidades populares sejam ouvidas e acatadas em um processo dialógico.

\section{4 É preciso deliberar para decidir sobre políticas públicas: aspectos conceituais}

Em 1992, Habermas publica a obra Faktizität und Geltung, cuja concepção de democracia inclui o papel da esfera pública como imprescindível e discute sua influência sobre o campo político, formulando um projeto de institucionalização orientado pelo paradigma procedimental de democracia. No Brasil, a obra foi publicada em 1997, com o título Direito e democracia: entre facticidade e validade.

Em $A$ inclusão do outro, de 2004, o autor apresenta o modelo de "política deliberativa", ou procedimentalista, que tem como base as condições de comunicação através das quais o processo político se torna capaz de alcançar resultados racionais, exatamente por cumprir-se, em todo o seu processo, de modo deliberativo.

Esse procedimento democrático, também denominado Teoria do Discurso, gera uma coesão interna entre negociações, discursos de autoentendimento e sobre a justiça e fundamenta a afirmativa de que sob tais condições se busca encontrar resultados ora racionais, ora justos e honestos (Habermas, 2004, p. 286).

Para Habermas, o procedimento deliberativo tem o condão de contribuir para que o poder político deixe de figurar como mero agregado ao ser orientado pela opinião e vontade da população, que, então, não exercerá somente posteriormente o controle do exercício do poder, também participando de sua programação. Assim, a opinião pública transformada em ação comunicativa segundo procedimentos democráticos não pretende 
dominar, mas sim auxiliar direcionando a administração pública a tomar determinados caminhos (Habermas, 2004, p. 290).

A política deliberativa, dessa maneira, manifesta-se por duas vias: primeiramente, a formação da vontade democraticamente constituída em espaços institucionais e, no segundo momento, a construção da opinião informal em espaços extra-institucionais. A inter-relação entre esses dois espaços é que pode assegurar um governo legítimo. A deliberação consiste num processo de discussão e avaliação em que os distintos aspectos de determinada proposta são considerados. Isso pressupõe: a) a inclusão de todo e qualquer cidadão capaz de se comunicar a participar de discursos e discussões; b) a participação através da qual todo e qualquer ator de um discurso pode problematizar qualquer afirmação, introduzir novas questões, exprimir suas necessidades, anseios e experiências; e c) a comunicação livre de violência e coação, possibilitando que nenhum interlocutor seja impedido, por forças internas ou externas ao discurso, de fazer uso pleno de seus direitos, assegurados nos dois pressupostos anteriores.

Nesse viés, Carlos Santiago Nino também propõe a construção de uma teoria democrático-deliberativa fundada na deliberação coletiva como elemento essencial para a tomada de decisões de índole coletiva, já que se parte do pressuposto de igualdade e de que todos merecem igual respeito e consideração. A deliberação pública, para Nino, configura um ideal normativo e um teste para a legitimidade democrática, uma vez que a democracia só se justifica na medida em que permite a construção de um espaço público de deliberação.

E é nesse espaço, a esfera pública (estatal e/ou não estatal), que os cidadãos poderão deliberar qual a melhor decisão para suas vidas e que princípios e normas devem reger a sociedade em que vivem. Nino parte de uma concepção dialógica de democracia, na qual política e moral não se separam, mas sim determinam o valor da própria democracia (Nino, 1999, p. 154).

Pois bem, a teoria de Nino se inscreve dentro de sua mais ampla concepção acerca da justificação da democracia, pronunciando-se a favor de uma concepção deliberativa. Para o autor, essa concepção da democracia aparece como sucedâneo imperfeito de um discurso moral ideal no qual, 
sem limites de tempo, com informação plena e com o intuito de aperfeiçoar a discussão até encontrar um acordo unânime, os membros de uma sociedade fixam as bases a partir das quais organizam sua vida em comum. O resultado de acordos alcançados em um discurso moral ideal será denominado resultado imparcial, na medida em que expressa um balanço adequado dos pontos de vista de diferentes integrantes da sociedade. E, nesse sentido, a democracia deliberativa lhe parece o instrumento mais adequado que se tem ao alcance para favorecer a tomada de decisões imparciais.

A democracia deliberativa, assim, se aproxima do discurso ideal na medida em que se torna mais eficaz na promoção de suas promessas básicas: favorecer a inclusão social e promover entre seus membros uma verdadeira troca de ideias e de argumentos. Isso porque faz parte do ideal de democracia deliberativa que todos os indivíduos afetados por um processo de tomada de decisões possam dele participar e que esta ocorra em um processo de discussão pública em que cada uma das propostas que se considerem apareça fundada em razões que todos os demais possam revisar e discutir de maneira apropriada, baseando-se na premissa de que cada indivíduo é o melhor juiz de seus próprios interesses.

A esse respeito, adverte Gargarella, que mesmo que a distância existente entre os representantes políticos e a população fosse diminuída, ainda assim haveria uma falha no processo democrático adotado sem a participação popular, visto que as questões públicas mais relevantes continuariam a ser decididas por poucos e não por muitos (Gargarella, 2008, p. 261). Tal proposta de igualdade na participação e nas decisões dos assuntos que afetam à sociedade busca reinstalar uma dimensão igualitária que se perde quando a vida coletiva fica sujeita ao resultado do incentivo e de iniciativas de uma minoria poderosa (Gargarella, 2008. p. 262).

Como se pode observar, para que as políticas públicas atendam aos anseios, às necessidades e carências por meio de ações conjuntas, é necessária a participação da coletividade desde a sua formulação à sua deliberação. Essa é também uma demanda por igualdade.

\section{5 É preciso ter um plano de política pública}

O Plano Nacional do Livro e Leitura (PNLL) foi instituído em 2006, pelos então ministros da Cultura, Gilberto Passos Gil Moreira, e da 
Educação, Fernando Haddad, e, em 2011, foi promulgado por meio do Decreto $\mathrm{n}^{0}$ 7.559, firmado pela presidente Dilma Roussef. Foi elaborado com base em mais de 150 reuniões públicas celebradas em todo o País, entre os anos de 2005 e 2006, nas quais diversas sugestões para sua construção foram colhidas.

Nessas ocasiões foram ouvidos editores, livreiros, distribuidores, gráficas, fabricantes de papel, escritores, administradores, gestores públicos e outros profissionais do livro, educadores, bibliotecários, universidades, especialistas em livro e leitura, organizações da sociedade, empresas públicas e privadas, governos estaduais, prefeituras e interessados em geral.

Para José Castilho Marques Neto, o Brasil alcançou com o PNLL um patamar político e conceitual
que é imprescindível para se consolidar uma Política de
Estado para o setor, isto é, o desejado consenso entre
governo e sociedade tanto no diagnóstico do que é preciso
fazer quanto nos objetivos a alcançar para se tornar um
país de leitores (2010, p. 14).

As diretrizes do PNLL, segundo o MINC, têm como objetivo a formação de uma sociedade leitora, como condição essencial para promoção da inclusão social de milhões de brasileiros no que tange ao acesso aos bens, serviços e direitos culturais, em atendimento ao princípio da dignidade humana e acreditando na estruturação de um país economicamente viável.

As diretrizes para uma política pública voltada à leitura e ao livro no Brasil (e, em particular, à biblioteca e à formação de mediadores), apresentadas pelo PNLL, levam em consideração o papel de destaque que essas instâncias assumem no desenvolvimento social e da cidadania e nas transformações necessárias da sociedade para que esta seja mais justa. Elas se fundam no fato de o governo central admitir a necessidade de constituir uma sociedade leitora, como pressuposto para diminuição das desigualdades, na medida em que também propicia a estruturação de um país economicamente mais forte.

São quatro os eixos que definem a organização do PNLL: 1 democratização do acesso; 2 - fomento à leitura e à formação de mediadores; 3 - valorização institucional da leitura e incremento de seu valor simbólico; 4 - desenvolvimento da economia do livro. 
O Governo Federal, ao instituir o PNLL, buscou imprimir-lhe a dimensão de uma Política de Estado abrangente, cuja função é a de nortear políticas, programas, projetos e ações continuadas, desenvolvidos pelos ministérios - com ênfase nos da Cultura e da Educação -, assim como pelos governos estaduais e municipais, empresas públicas ou privadas, organizações da sociedade e, em especial, todos os entes que tenham interesse.

Na edição atualizada e revisada do Caderno do PNLL de 2014 (que vem a ser, em outras palavras, o próprio PNLL, do qual foram extraídas as presentes informações, editado e disponibilizado pelo MINC em seu sítio (www.cultura.gov.br/), afirma-se que, para fortalecer qualquer política ou ação ligada ao livro, é preciso que se valorize a cultura em sua totalidade, viabilizando o acesso aos mais diversos bens culturais que estabelecem vínculos estreitos com os livros. No que tange à necessidade de implementação de Políticas Públicas de Leitura, admite o Governo Federal, no referido Caderno, que a leitura e a escrita devem ser consideradas base em processos de formulação e implantação de políticas públicas de educação e cultura dos governos em todos os seus níveis e modalidades de ensino e de administração, tal como proposto no Plano Nacional de Cultura (PNC), instituído pela Lei n. 12.343, de 2 de dezembro de 2010.

A consolidação de políticas e programas de fomento à leitura deve ser pensada em curto, médio e longo prazo, com ênfase no caráter permanente. Nesse processo, o fomento e a elaboração de Planos Estaduais e Municipais do Livro e Leitura articulados com o Plano Nacional se tornam fundamentais.

O objetivo de instituir-se o PNLL foi assegurar e democratizar o acesso à leitura, ao livro, à literatura e às bibliotecas a toda a sociedade, com base na compreensão de que a leitura e a escrita são instrumentos indispensáveis para que o ser humano possa desenvolver plenamente suas capacidades, seja individual ou coletivamente.

Há a convicção de que somente assim é possível que, na sociedade da informação e do conhecimento, o cidadão exerça de maneira integral seus direitos, participe efetivamente dessa sociedade, melhore, em amplo sentido, seu nível educativo e cultural, fortaleça os valores democráticos, 
seja criativo, conheça outras culturas, valores e modos de pensar de outras pessoas e tenha acesso às formas mais verticais do conhecimento.

Busca-se criar condições necessárias e apontar diretrizes para a execução de políticas, programas, projetos e ações continuadas por parte do Estado em suas diferentes esferas de governo e também por parte das múltiplas organizações da sociedade civil, objetivando a promoção da cidadania e inclusão social, para uma ação com organização social mais justa. (Brasil, 2014, p. 23).

Em que pese a inovadora iniciativa que foi, em 2006, a elaboração do PNLL, vale dizer que ainda se encontra em tramitação, no MinC e no MEC, o projeto de lei sobre Plano Nacional do Livro e Leitura, que deve ser encaminhado ao Congresso Nacional, para que se torne uma lei, institucionalizando as políticas públicas relativas ao livro, à leitura, à literatura e às bibliotecas. O PNLL representou a inspiração para a existência da Política Pública de Leitura que será analisada a seguir, Programa Curitiba Lê, instituído e desenvolvido pela Fundação Cultural de Curitiba.

\subsection{Plano Estadual do Livro, Leitura e Literatura do Paraná (PELLL)}

O Estado do Paraná, em alinhamento com o PNLL, instituiu o Plano Estadual do Livro, Leitura e Literatura (PELLL), com o objetivo de delinear os rumos das políticas públicas na difusão da leitura no Estado, e foi aprovado em 24 de março de 2013, pela Assembleia Legislativa do Paraná. A elaboração do PELLL foi coordenada pela Biblioteca Pública do Paraná, procurando definir políticas públicas que visam à democratização do acesso ao livro e à valorização da leitura. $\mathrm{O}$ plano foi sancionado pelo governo estadual, Lei n. 17.547 de 17 de abril de 2013.

A elaboração do Plano Estadual do Livro teve início em 2010, pelas Secretarias de Estado da Educação (SEED) e da Cultura (SEEC), por meio da Biblioteca Pública do Paraná, e foi apresentado no ano de 2011, definindo metas para o setor da leitura pelos próximos 10 anos. Para tanto foram realizadas três audiências públicas - em Curitiba, Maringá e Foz do Iguaçu, em que foi apresentada a minuta do Plano proposto e, após, foram coletadas sugestões da sociedade em geral. 
Além da comissão composta por especialistas que redigiram o texto e das audiências realizadas com a população, a SEEC utilizou como base para a elaboração do PELLL paranaense a pesquisa Retratos da Leitura no Paraná, realizada em 2010, pela Paraná Pesquisas ${ }^{6}$.

O PELLL tem como meta reunir, organizar e garantir continuidade às ações na área do livro, leitura e literatura ao longo dos anos. Contudo, o Plano, isoladamente, não confere garantia de acesso ao livro e à leitura. Para que o acesso se viabilize, há necessidade de ações concretas, alinhadas com a União (PNLL), Município e sociedade, de caráter continuado, que busque atingir o maior número possível de pessoas da comunidade, indistintamente?.

Seguindo as orientações do Plano Nacional do Livro e Leitura, o PELLL paranaense é orientado por quatro eixos principais: democratização do acesso ao livro, fomento à leitura e à formação de mediadores, valorização da leitura e comunicação e desenvolvimento da economia do livro. No que diz respeito à descentralização da cultura no Paraná, o Plano pretende levar às cidades do interior ações de leitura, além de promover o Prêmio Paraná de Literatura, com o objetivo de estimular, fomentar e reconhecer as melhores experiências que promovam a literatura em âmbito nacional, nas categorias poesia, conto e romance.

\section{POLÍtICA PÚBLICA DE CULTURA - PROGRAMA CURITIBA L $\mathrm{L}$}

O Programa Curitiba Lê teve início em 2010, instituído pela Fundação Cultural de Curitiba (FCC) ${ }^{8}$ e elaborado por uma equipe da

6 Em parceria com o jornal local Gazeta do Povo, a gráfica Posigraf e com o deputado federal Marcelo Almeida.

7 Ao ser instituído, o Plano Estadual do Livro, Leitura e Literatura do Paraná (PELLL) expôs no artigo $1^{\mathrm{o}}$ "a finalidade de desenvolver e assegurar estratégias permanentes de planejamento, apoio e articulação para a execução de ações voltadas para o fomento da produção e circulação do livro, da leitura e da literatura no Paraná" e no artigo $2^{\circ}$ define os objetivos e anuncia sua consonância com as diretrizes do PNLL ao pretender diagnosticar, incentivar e promover ações na área do livro, leitura e literatura, tendo em vista: a democratização do acesso ao livro; a formação de mediadores para o incentivo à leitura; a valorização da leitura e sua interface com a comunicação; o desenvolvimento da economia do livro; o estímulo à criação, produção e circulação da produção literária paranaense.

8 A FCC foi criada em 1973, como parte das ações de planejamento, para uma política de preservação da cultura e da história da cidade. No início dos anos 1970, foi definido o Setor Histórico, criado o Centro de Criatividade de Curitiba e inaugurado o Teatro do Paiol, o que contribuiu para a estruturação de um órgão municipal para gerenciar a as 
própria $\mathrm{FCC}^{9}$, consiste num conjunto de ações na área da Literatura diretamente desenvolvidas pela FCC ou em parceria com outras instituições públicas, iniciativa privada ou organizações não governamentais. O objetivo do PCL é envolver os moradores da cidade nessas ações, aumentando qualitativa e quantitativamente os índices de leitura das pessoas.

Para tanto, a FCC providenciou a implantação de espaços físicos adequados e suas designações, além de estabelecer as políticas culturais de leitura como um serviço público a ser prestado à comunidade, visando a garantir seus direitos de acesso à arte e à cultura. O PCL criou treze novos espaços denominados Casas da Leitura, localizadas em diversos bairros de Curitiba, quais sejam: Casa da Leitura Manoel Carlos Karam, Dario Vellozo, Augusto Stresser, Hilda Hilst, Jamil Snege, Maria Nicolas, Miguel de Cervantes, Nair de Macedo, Osman Lins, Paulo Leminski, Walmor Marcelino, Wilson Bueno, Wilson Martins.

As Casas de Leitura possuem acervo bibliográfico específico, utilizado para leitura local e também para empréstimos. Além desse serviço, administram as rodas e ciclos de leitura, as contações de histórias e as visitas monitoradas. Ambientações para leitura nos locais também foram providenciadas, bem como um espaço para as crianças, para as oficinas de criação, para as rodas de leitura e demais cursos.

Diferenciam-se das bibliotecas por terem seus acervos voltados à literatura e outras linguagens artísticas, além de sua preocupação social em mudar o quadro de leitura da população por meio de ações específicas de leitura.

Além das Casas de Leitura ainda existem outros pontos, tais como o Bondinho da Leitura e a Estação da Leitura, que pertencem ao mesmo programa. A Estação da Leitura, inaugurada em 2010, funciona dentro do

atividades culturais, que, até então, ficavam sob responsabilidade do Departamento de Relações Públicas e Promoções da Prefeitura. Desde então, a FCC é o órgão responsável pela política pública municipal de cultura, atuando em conjunto com os setores privados e com as organizações não governamentais. À FCC cabe atuar no sentido de atender às demandas sociais de cultura no Município de Curitiba, promovendo a produção e o acesso a bens e equipamentos culturais, a preservação do patrimônio cultural material e imaterial e a valorização das manifestações culturais tradicionais ou emergentes. Deve também proporcionar os meios para que os artistas, os produtores e os movimentos culturais ampliem gradativamente o protagonismo tanto na ação cultural quanto no controle social sobre as políticas públicas.

9 Mauro Tietz, com colaboração e revisão de Mariane Filipak Torres e Patrícia Wohlke. Foi atualizado em 2015 por Mariane Filipak Torres, Patrícia Wohlke e Marcelo Henrique Frote. 
Terminal de Ônibus do Pinheirinho e conta com um equipamento desenvolvido especialmente para esse projeto. O espaço físico da Estação comporta aproximadamente 4.000 volumes de literatura para todas as faixas etárias e atende aos passageiros do transporte público por meio de um sistema que agiliza o empréstimo e as devoluções dos livros.

O Bondinho da Leitura é um antigo bonde elétrico situado no coração de Curitiba, na rua XV de Novembro, no ponto reservado para pedestres designado Boca Maldita, e era utilizado para o desenvolvimento de atividades nas várias linguagens artísticas. Em 2010 foi adaptado para funcionar como biblioteca. Disponibiliza para empréstimos, de maneira simples e ágil, um acervo de aproximadamente 5.000 volumes de literatura para todas as faixas etárias.

No movimento de descentralização das ações culturais, intencionando atingir mais regiões e comunidades do município, a FCC atua também nas Unidades Regionais, que surgiram em 1986, em Curitiba, para auxiliar na administração da diversidade, das características particulares e das necessidades próprias de cada bairro e região.

Descentralizando os serviços da Prefeitura, cada Regional atua como uma subprefeitura, sendo responsável pela identificação das prioridades de cada macrorregião. Atualmente, a cidade conta com nove Regionais, que devem monitorar as ações das secretarias municipais, incluindo as ações da FCC, ajudando na organização dos serviços oferecidos à comunidade e fazendo com que o planejamento local seja integrado ao planejamento da cidade. Os Núcleos Regionais atendidos pela FCC são: Regional Bairro Novo, Regional Boa Vista, Regional Boqueirão, Regional Cajuru, Regional CIC, Regional Matriz, Regional Pinheirinho, Regional Portão e Regional Santa Felicidade.

Não se destina este estudo a descrever em pormenores as atividades do Programa Curitiba Lê, mesmo porque elas se encontram descritas no sítio da FCC, disponível para consulta a qualquer interessado. Porém, as ações primordiais são aqui elencadas para melhor compreensão do PCL em sua abrangência.

As ações de leitura concentram-se em dois campos de atuação. O primeiro é desenvolvido diretamente junto à população com o objetivo de incentivar as pessoas a praticar mais e melhor a leitura, e é designado pelo 
PCL como Área de Incentivo à Leitura. O segundo visa à formação de mediadores de leitura, com foco na formação de agentes multiplicadores e é denominado Área de Estudos e Pesquisas em Leitura. Um terceiro campo de trabalho se constitui na Área de Criação Literária.

\section{Área de incentivo à leitura}

Efetua ações diretas junto à comunidade no intuito de despertar as atenções para o universo da literatura e dos livros. Essas atividades são realizadas tanto nos espaços físicos do projeto como em outros locais da comunidade em nome das Casas de Leitura e são desenvolvidas geralmente com grupos, quais sejam: 1. rodas e ciclos de leitura, isto é, encontros entre um mediador de leitura e o público, nos quais o mediador sugere a leitura de determinado texto, expõe suas leituras desse texto e acolhe as leituras dos participantes, estimulando conversas, questionamentos e reflexões sobre o texto base durante o processo; 2. ciclos de leitura, compostos por várias Rodas de Leitura, interligadas entre si por um elemento que imprime ao conjunto das Rodas uma conexão entre elas como por exemplo, ciclo de leituras das obras completas de um escritor, ciclo de leituras de obras da antiguidade, ciclo de leituras de obras para o público jovem, entre outras; 3. contações de histórias, isto é, ações que visam ao incentivo à leitura, bem como a chamar a atenção do público participante para o conteúdo dos livros através de histórias narradas, vindas da tradição oral ou dos livros, que estimulam a busca por novas histórias - ouvidas ou lidas.

\section{Área de estudos e pesquisas em leitura}

Tem como objetivo tomar a leitura como objeto de estudos e pesquisa, realizando para tal a formação de Mediadores de Leitura, com vistas a implantar práticas de incentivo à leitura junto à população. As principais atividades desenvolvidas para atingir essas metas são: 1. Laboratórios de Leitura, isto é, laboratórios de formação continuada que realizam a formação dos Mediadores de Leitura, tanto em fundamentação teórica e troca de experiências quanto no que diz respeito às ações práticas para a comunidade. São espaços nos quais os participantes, sob a orientação de um responsável, realizam um percurso de estudos, discussões e reflexões sobre a leitura. Essa atividade propõe que os integrantes edifiquem sua própria formação enquanto leitores, para poderem conceber e aplicar, ao término do período, projetos de incentivo à leitura junto à população; 2. 
Seminários e oficinas, isto é, ações através das quais se configura e se consolida um espaço de aquisição de conhecimentos e reflexões sobre leitura, dirigidas por profissionais que pesquisam e atuam na área da literatura, livro e leitura. O objetivo dessas ações é manter atualizadas as discussões e reflexões sobre a literatura; 3. Supervisões técnicas dizem respeito aos encontros que têm como objetivo promover a troca e análise de experiências de trabalho dos profissionais que atuam direta ou indiretamente com a coordenação de literatura, à luz do conhecimento teórico e prático de um profissional especialmente convidado para conduzir o encontro de supervisão técnica, nos quais os profissionais locais relatam suas experiências e propõem temas ao supervisor no intuito de aprimorar as reflexões e a qualidade das ações desenvolvidas; 4. Formação Continuada dos profissionais que atuam nos espaços de leitura: os funcionários da FCC que participam de encontros semanais nos quais leem literatura, estudam teoria literária e teoria da leitura, visando a que desenvolvam uma compreensão mais profunda sobre as propostas PCL e, consequentemente, um desempenho mais qualificado de suas atividades.

\section{Área de criação literária}

São oficinas de análise e criação literária que procuram auxiliar no ofício da escrita literária através da leitura e análise da obra de escritores consagrados por público e crítica, criando referências para os participantes e propondo aos mesmos exercícios de criação e produção própria de textos.

Além dessas ações, existem as Casas da leitura, o Bondinho e a Estação da Leitura, já mencionados.

Por meio das ações desenvolvidas pela Coordenação de Literatura no PCL, é possível reconhecer o alinhamento desse programa com as diretrizes do Plano Nacional de Cultura e do Plano Nacional do Livro e da Leitura. Todavia, para realizar a tarefa de avaliar qualitativamente uma política cultural, se deve ter uma espécie de modelo analítico, cujas dimensões são inerentes às políticas culturais (Rubim, 2007, p. 149). Vejamos: 1. determinar a noção de política acionada, como momento sempre presente em toda e qualquer política cultural; 2. definir a cultura intrínseca à política cultural analisada, por ter incidência sobre a amplitude dessa política; 3 . investigar as formulações, condensadas em planos, programas, projetos e demais ações, analisando as conexões e contradições entre eles; 4. analisar 
os objetivos e metas da política cultural; 5. delimitar e caracterizar os atores das políticas culturais, ressaltando que o Estado deixou de ser o ator principal; 6. elucidar os públicos pretendidos, determinar quais os públicos visados e quais as modalidades de fruição e de consumo previstas e inscritas nas políticas culturais; 7. analisar quais foram os instrumentos, meios e recursos acionados, sejam eles humanos, legais, materiais (instalações, equipamentos etc.), financeiros, entre outros; 8. avaliar os momentos da política cultural, e quais foram priorizados (criação, circulação difusão, outros).

\subsection{Programa Curitiba Lê: análise}

Seguindo a lógica proposta por Rubim, acima descrita, discorrer-se-á sobre a adequação do PCL aos critérios de avaliação de política cultural, com o intuito de efetuar uma avaliação que permeie os vários aspectos inerentes ao programa. Dessa maneira, a presente análise não se aterá a avaliar um critério da ação, e, sim, incursionará pelos vários critérios propostos por Rubim, a fim de se constatar a amplitude do PCL como programa que possui características e envergadura de uma verdadeira Política Pública de Leitura.

Primeiramente, em se tratando de comentar o tipo de ação política praticada pela FCC ao instituir o PCL, deve-se enfatizar o caráter democrático e participativo da política pública do PCL. Em respeito aos preceitos da $\mathrm{CF} / 88$ e em alinhamento com o PNC, o PNLL, assim como com o PELLL, o Programa Curitiba Lê foi elaborado após a realização de audiências públicas que envolveram representantes de todos os segmentos culturais da cidade; do poder público e da iniciativa privada, como artistas, produtores culturais, funcionários públicos do setor, entre outros. E ainda, a formação e multiplicação de mediadores promove a inclusão da população para o PCL, de forma heterogênea e múltipla.

Portanto, quanto ao tipo de política adotada, trata-se de uma política pública democrática e horizontalizada no sentido de que envolve, desde sua concepção, não somente membros do poder público, mas também de toda a comunidade. Ademais, a localização estratégica dos aparelhos possibilita o acesso, indistintamente, de qualquer pessoa da população ao acervo literário da FCC, além das instituições atendidas pelo programa. Esse é, sem dúvida, um caráter democratizante do PCL. 
O direito à leitura é uma via de acesso a outros bens e direitos culturais, sociais, econômicos, políticos, direito à informação, à tecnologia, entre outros constitucionalmente consagrados. Ao defender o direito de todos à leitura, não se está se referindo à leitura erudita ou à alta literatura, sem, contudo, desprezá-las ou descartá-las, mas sim de proporcionar ao cidadão condições de viver dignamente, em situação de igualdade com os demais, que são os que sabem ler e praticam o hábito da leitura.

A leitura é uma ferramenta para o crescimento individual e social do ser humano, e por essa razão ações culturais como o PCL tornam-se imprescindíveis para o desenvolvimento local, regional e geral.

Desde o início deste trabalho, a cultura, e para o presente caso, a leitura, está relacionada com as mais essenciais e profundas necessidades humanas, configurando um direito humano fundamental. Segundo Antonio Candido "(u)ma sociedade justa pressupõe o respeito dos direitos humanos e a fruição da arte e da literatura em todas as modalidades e em todos os níveis, que é um direito inalienável" (Candido, 2012, p. 191).

Partindo dessa compreensão acerca da importância da leitura para o ser humano eis a necessidade da instituição e manutenção de uma política pública que incentiva e difunde essa prática para todos.

Acreditando na utilidade pública do PCL, toda a equipe da FCC que compõe a área de Literatura esteve presente, durante os dias 18, 19 e 20 de dezembro de 2015, na V Conferência Municipal de Cultura, na qual, enfim, o Programa Curitiba Lê foi elevado ao patamar de política pública de leitura que, a partir de então, deve permear todas as gestões municipais, independentemente de partidos políticos ou preferências pessoais dos gestores.

Num terceiro momento, pode-se observar que as formulações e ações desenvolvidas e implementadas pelo PCL possuem, desde sua implantação, caráter de continuidade, pois já ingressam em seu sexto ano de vida em atividade. Somente duas ações não prosseguiram e foram eliminadas após o primeiro ano do PCL: a ação denominada "Coleção Cidade de Curitiba", que propunha a publicação de títulos desenvolvidos por participantes do programa; e a publicação de 1000 exemplares ao ano do "Jornal das Oficinas de Análise e Criação Literária”. As demais ações, acima 
mencionadas, se mantêm ano após ano, assim como mantêm-se a frequência da comunidade, como se depreende dos gráficos anexados a este trabalho.

No que concerne aos atores, o PCL, desde sua concepção, contou com a comunidade epistêmica da área das letras e da literatura, integrantes da comunidade, Organizações não Governamentais, funcionários da FCC, funcionários da PMC e escritores. A partir de maio de 2012, o ICAC (Instituto Curitiba de Arte e Cultura) é agregado ao Programa por meio de contrato de gestão assinado com a Prefeitura Municipal, passando a ser o responsável pela contratação e pelo pagamento dos mediadores de leitura e dos funcionários de apoio que atuem diretamente nas Casas da Leitura.

No que concerne ao público que o PCL pretende atingir, não há uma definição ou critério seletivo para tal. Existem ações voltadas para o público infantil, para os jovens e também para adultos, indistintamente e independentemente de idade, sexo, grau de instrução, bairro onde reside, estado civil e outras particularidades. Ademais, existe um público atingido pelo PCL que, embora não frequente as oficinas e cursos, é beneficiado e agraciado com as ações do programa.

As instituições atendidas pelo PCL, que ao total somam centenas de estabelecimentos, são escolas particulares, municipais e estaduais; ONGs (Organizações Não Governamentais), Institutos Assistenciais, abrigos da FAS (Fundação de Assistência Social), UFPR (Universidade Federal do Paraná), SENAC (Serviço Nacional do Comércio), SESI (Serviço Social da Indústria), COHAB (Companhia de Habitação do Paraná), Polícia Militar do Paraná, associações sem fins lucrativos, entre outros. No ano de 2014, por exemplo, foram atendidas 384 (trezentas e oitenta e quatro) instituições ao todo.

Dessa maneira, pode-se afirmar que o público atingido pelo PCL é constituído por todos os tipos de cidadãos que habitam a cidade de Curitiba: menores infratores recolhidos pela FAS; alunos de colégios particulares; estudantes universitários; funcionários públicos, alunos da rede pública de ensino, policiais e seus dependentes, cidadãos comuns, entre outros. Essa característica incrementa o aspecto democrático do PCL e demonstra sua capilaridade nos mais variados setores da sociedade. 
Os instrumentos, meios e recursos utilizados pela FCC para realização do PCL demonstram preocupação em descentralizar as ações de leitura, no sentido de que as regionais foram aparelhadas para recepção das ações do programa e ainda, os Editais publicados pela FCC periodicamente são abertos a toda a comunidade; trata-se de um meio de divulgação oficial e de larga abrangência, que não fica restrito à apreciação e ao conhecimento de um pequeno grupo de cidadãos. Qualquer interessado pode acessar os editais e se candidatar, apresentando um projeto que acrescente ações positivas para o desenvolvimento do programa.

Além disso, a formação de mediadores de leitura proporciona um crescimento geométrico do número de agentes capazes de agir nos vários setores sociais. Nos Laboratórios de Leitura, os participantes aprendem como elaborar projetos de leitura que atendam às demandas da comunidade. Cada mediador de leitura é um disseminador da leitura em potencial, criando-se uma cadeia em constante crescimento.

As verbas do PCL são oriundas do Fundo Municipal de Cultura. Ademais, os projetos também são subsidiados pela Lei Municipal de Incentivo à Cultura, por meio da publicação dos editais específicos, que com sua composição e destinação de verbas permitem a manutenção das ações do programa. Os editais de formação de mediadores, de criação literária e de ações de incentivo à leitura são lançados periodicamente. O de Publicações em Literatura não possui periodicidade determinada, mas como resultado de sua primeira edição houve o lançamento da Coleção Cidade de Curitiba, que tinha como objetivo divulgar escritores radicados em Curitiba, mediante a publicação de seus livros.

O Fundo Municipal de Cultura é constituído por financiamentos reembolsáveis e não reembolsáveis e consiste no tipo de financiamento público cujas fontes têm origem orçamentária, mas não só. Tais financiamentos são aplicados a fundo perdido, sem expectativa de retorno, e o modo de assegurar a democratização no acesso aos recursos do Fundo é a seleção pública dos projetos propostos. O Fundo possui conta bancária própria, ao contrário do orçamento, que pertence ao caixa único da Prefeitura já que pode contar com recursos de outras fontes.

O incentivo é oriundo da renúncia fiscal, pela Prefeitura de Curitiba, de até $2 \%$ da arrecadação de Imposto Predial e Territorial Urbano (IPTU) e 
Imposto Sobre Serviços (ISS). Atualmente representa uma das mais importantes fontes de subsídio para a produção cultural na cidade. Por meio da Lei de Incentivo são realizados espetáculos teatrais, vídeos, livros, filmes, exposições, CDs, publicações sobre a história do município, projetos de cursos, palestras, séries de concertos e shows, entre outros produtos que representam a maior parte da produção cultural curitibana.

\subsubsection{Dados gerais do PCL}

Na sequência serão apresentados os dados gerais tabulados do PCL, tais como participantes, beneficiados $\mathrm{x}$ investimentos, entidades $\mathrm{e}$ instituições.

Figura 2-Participantes do PCL, relação beneficiados PCL x investimentos, relação de entidades e instituições atendidas pelo PCL

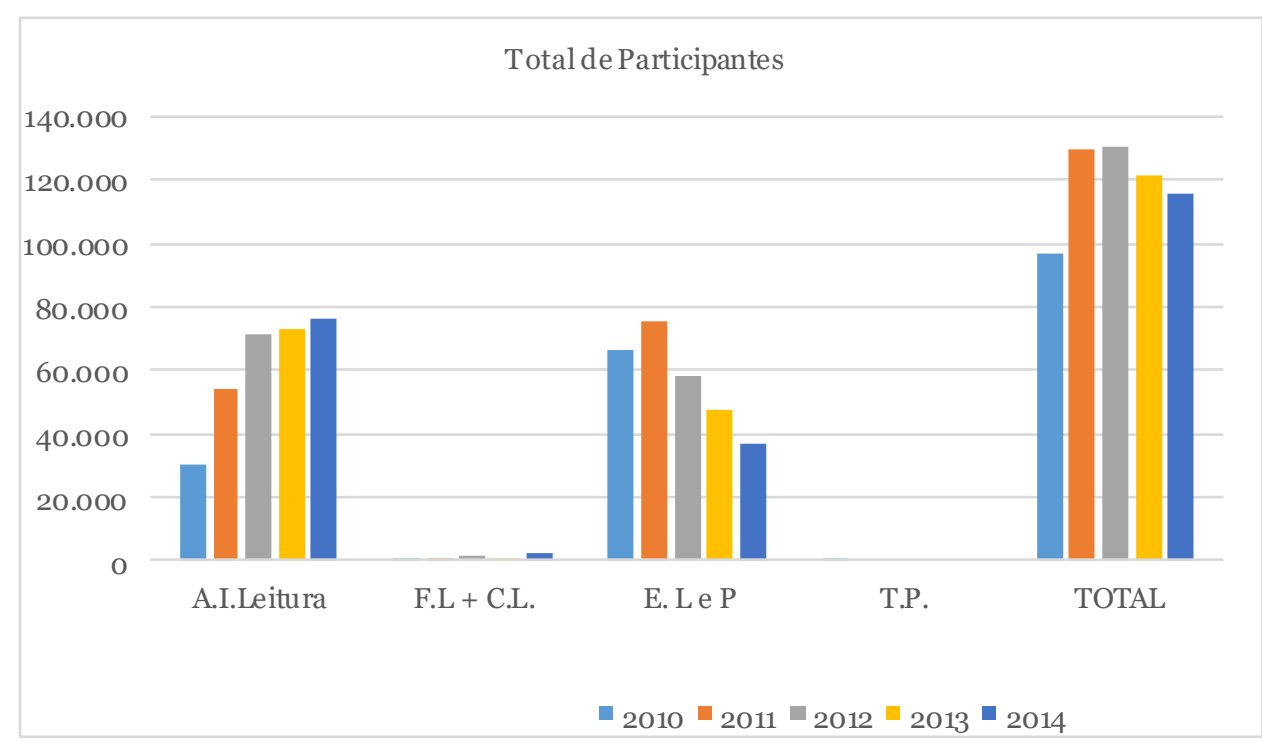

Fonte: Elaborado pelas autoras.

Tabela 1 - PCL: atividades

\begin{tabular}{l|l|l|l|l|l}
\hline & 2010 & 2011 & 2012 & 2013 & 2014 \\
\hline A.I.Leitura & 30.118 & 54.057 & 71.135 & 72.991 & 76.612 \\
\hline F.L + C.L. & 392 & 332 & 1.792 & 306 & 2.339 \\
\hline E. Le P & 66.465 & 75.243 & 57.819 & 47.829 & 36.595 \\
\hline T.P. & 4 & 0 & 0 & 0 & 0 \\
\hline Total & 96.979 & 129.632 & 130.746 & 121.126 & 115.546 \\
\hline
\end{tabular}

Fonte: FCC

Notas

A.I.Leitura: Atividades de Incentivo à Leitura (Rodas de Leitura e Contações de Histórias)

F.L. + C.L: Formação em Leitura e Criação Literária

E.L e P: Empréstimos de Livros e Periódicos

T.P: Títulos Publicados 
Tabela 2 - PCL: investimentos e participantes

\begin{tabular}{l|l}
\hline Ano e valor do edital & Total de participantes \\
\hline $2010-\mathrm{R} \$ 1.058 .000,00$ & 96.979 participantes \\
\hline $2011-\mathrm{R} \$ 1.125 .500,00$ & 129.632 participantes \\
$2012-\ldots$ & 130.746 participantes \\
\hline $2013-\mathrm{R} \$ 1.665 .000,00$ & 121.126 participantes \\
\hline $2014-\mathrm{R} \$ 411.000,00$ & 115.546 participantes \\
\hline
\end{tabular}

Fonte: FCC

Quadro 2 - Dados do PCL (2010-20140

\begin{tabular}{|ll|}
\hline DE 2010 a 2014 & 60 MESES \\
\hline TOTAL DE PARTICIPANTES: & 594.029 pessoas \\
\hline MÉDIA DE PARTICIPANTES a.a: & 118.806 pessoas \\
\hline TOTAL DO INVESTIMENTO/EDITAIS: & $\mathrm{R} \$ 4.259 .500,00$ \\
\hline MÉDIA DE INVESTIMENTO a.a NO PCL: & $\mathrm{R} \$ 851.900,00$ \\
\hline GASTO MENSAL POR CIDADÃO BENEFICIADO: & $\mathrm{R} \$ 7,17$ \\
\hline
\end{tabular}

Fonte: Elaborado pelas autoras

Figura 3-Participantes do PCL, relação beneficiados PCL x investimentos, relação de entidades e instituições atendidas pelo PCL

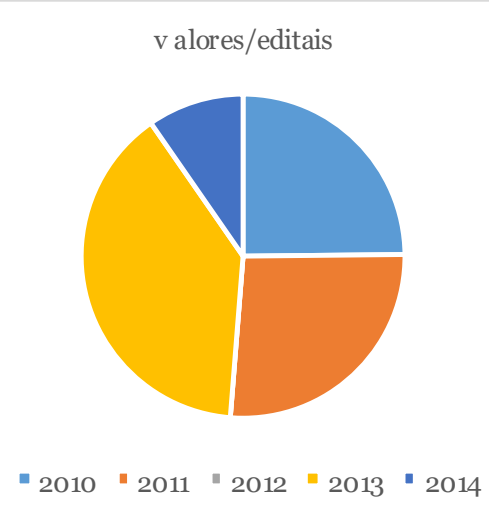

Fonte: Elaborado pelas autoras

Tabela 3 - PCL: dados gerais

\begin{tabular}{|l|l|l|l|l|l|l|}
\hline ano & $\begin{array}{l}\text { total de } \\
\text { instituições } \\
\text { atendidas a.a }\end{array}$ & $\begin{array}{l}\text { número } \\
\text { de pessoas }\end{array}$ & $\begin{array}{l}\text { investimen } \\
\text { to através } \\
\text { dos editais } \\
\text { em reais }\end{array}$ & $\begin{array}{l}\text { número de } \\
\text { editais } \\
\text { lançados }\end{array}$ & $\begin{array}{l}\text { número de } \\
\text { bairros } \\
\text { atendidos }\end{array}$ & $\begin{array}{l}\text { gasto por } \\
\text { cidadão ao ano } \\
\text { em reais }\end{array}$ \\
\hline 2010 & 270 & 96.979 & 1.058 .000 & 4 & 35 & 10,91 \\
\hline 2011 & 394 & 129.632 & 1.125 .500 & 4 & 51 & 8,68 \\
\hline 2012 & 584 & 130.746 & & 0 & 64 & 0 \\
\hline 2013 & 417 & 121.126 & 1.665 .000 & 6 & 61 & 13,74 \\
\hline 2014 & 384 & 115.546 & 411.000 & 3 & 71 & 3,55 \\
\hline TOTAL & 2049 & 594.029 & 4.259 .500 & 17 & 282 & 36,88 \\
\hline
\end{tabular}

Fonte: FCC 


\subsection{Análise dos dados quantitativos do PCL}

Importa informar que, de 2010 a 2013, a FCC coletava somente, ano a ano, para publicar em seu banco de dados, o número de participantes (sem discriminar idade, sexo, grau de instrução), o número de bairros atendidos e o número de instituições contempladas com ações do PCL

\subsubsection{Bairros atendidos pelo PCL: 56,4}

A média de bairros atendidos ao ano pelo PCL perfaz 56,4 bairros. $\mathrm{O}$ município de Curitiba conta hoje com 75 (setenta e cinco) bairros, segundo informação disponibilizada pelo sítio do IPPUC (Instituto de Pesquisa e Planejamento Urbano de Curitiba) ${ }^{10}$. Vale ressaltar que, somente no ano de 2014, o PCL atendeu a 71 (setenta e um) bairros, como se depreende da Tabela 3, acima, ou seja, com o passar dos anos aumentou o número de bairros contemplados pelas ações de leitura. A média extraída é de 75,2\% (setenta e cinco, vírgula dois por cento) dos bairros de Curitiba atendidos, por ano, pelo PCL. Contudo, observa-se um aumento do número de bairros atendidos a cada ano.

\subsubsection{Habitantes (cidadãos) atingidos/participantes - percentual de habitantes atingidos pelo PCL em cinco $\operatorname{anos}(31,61 \%)$}

Em pesquisa realizada pelo IBGE, em 2010 Curitiba tinha 1.751.907 (um milhão, setecentos e cinquenta e um mil, novecentos e sete) habitantes, sendo que se estima que a cidade tenha hoje, segundo dado fornecido pelo IBGE na mesma página do referido sítio, 1.879.355 habitantes (um milhão, oitocentos e setenta e nove mil e trezentos e cinquenta e cinco). Diante dessas informações, pode-se afirmar que um número equivalente a 31,61\% dos habitantes de cidade foram, ativa ou passivamente, atingidos pelas ações de incentivo à leitura; número esse alcançado pela divisão do número estimado de habitantes do município de Curitiba pelo número de habitantes da cidade que foram atingidos pelo PCL. Essa porcentagem confirma o poder de ramificação e democratização do PCL.

\footnotetext{
${ }^{10} \mathrm{Cf} . \mathrm{em}:$

http://www.ippuc.org.br/visualizarfoto.php?doc=http://admsite.ippuc.org.br/arquivos/f otos/F131/F131 001 BR.jpg
} 


\subsubsection{Investimento - custo benefício}

\subsubsection{Investimento por pessoa: $R \$ 7,17$ a.a.}

No que diz respeito ao investimento dispendido pelos editais da PMC por meio da FCC para a realização das ações nos cinco anos avaliados pela presente pesquisa, o valor médio foi de $\mathrm{R} \$$ 7,37 a.a. (sete reais e dezessete centavos) gasto por cidadão envolvido no PCL por ano; quando se divide o total do valor investido no período estudado pelo número de pessoas atingidas ao todo.

Em 2012 a FCC não lançou nenhum edital, porém no decorrer desse ano ações oriundas dos editais lançados em 2011 cobriram os 12 meses de 2012, sem prejuízo do atendimento ao público referente às ações de leitura do PCL.

Em 2013, a FCC lançou seis editais, o que proporcionou no decorrer do ano de 2014 a concretização de muitas ações e grande número de atendimentos, tanto no que tange ao número de bairros atendidos (setenta e um dos setenta e cinco bairros da cidade foram contemplados com ações, ou seja, quase $100 \%$ dos bairros da cidade) quanto no número de participantes, que perfez o total de $\mathbf{1 1 5 . 5 4 6}$ (cento e quinze mil, quinhentos e quarenta e seis) pessoas.

Lembra-se que a média de participantes do PCL ao ano é de 118.806 (cento e dezoito mil, oitocentos e seis) habitantes, quando somados os participantes dos anos ora analisados de PCL e divididos por cinco.

\subsubsection{Média de investimento anual no programa}

O custo benefício do PCL fica estampado se for levado em conta que, ao longo de cinco anos de duração (2010 a 2014), o valor total dispendido pelo Município para o programa foi de $\mathrm{R} \$ 4.259 .500,00$, como se depreende da Tabela 3. Esse valor dividido pelo período ora analisado perfaz uma média de $\mathrm{R} \$$ 851.900,oo (oitocentos e cinquenta e um mil e novecentos reais) investidos no PCL ao ano ${ }^{11}$.

Assim, para este estudo foi efetuada uma média do PIB de Curitiba referente aos anos de 2010, 2011 e 2012, que perfez o total de 56.899.204 mil reais (cinquenta e seis bilhões, oitocentos e noventa e nove milhões e duzentos e quatro mil reais).

11 Cf. em: www.cidades.ibge.gov.br 


\subsubsection{Investimento da PMC a.a. por cidadão participante:}

A média de investimento da PMC por ano no PCL ficou em 851.900,00 (oitocentos e cinquenta e um mil e novecentos reais). Esse número coincide exatamente com o valor gasto anualmente por cidadão atingido pelo PCL, qual seja, $\mathrm{R} \$$ 7,17 a.a. (sete reais e dezessete centavos ao ano).

Em 2014, o investimento financeiro destinado ao PCL foi reduzido na ordem de mais de 50\% (cinquenta por cento) do valor destinado em 2013 para o mesmo programa. O número de meses para atendimento das ações caiu de cinquenta e sete para vinte meses, ou seja, quase $1 / 3$ do tempo de ações coberto pelo edital anterior.

$\mathrm{O}$ apego dos participantes ativos e passivos às atividades do PCL permitiu que até o ano de 2014 os dados colhidos fossem satisfatórios; todavia, a drástica redução dos investimentos da PMC a projetos da FCC pode ocasionar considerável queda no número de ações de leitura desenvolvidas pelo PCL, para não dizer sua completa extinção, que seria uma possibilidade quando findarem as atividades de leitura propostas pelos editais de 2014. Agora, entretanto, com o advento da V Conferência Municipal de Cultura ter adotado o PCL como programa permanente da área de Literatura da FCC, acredita-se que o PCL deva prosseguir sua trajetória no município de Curitiba de forma contínua e permanente.

Vale dizer que como participantes ativos, para efeitos desta análise, compreende-se o rol de cidadãos que levam as ações de leitura ao público: enquanto participante passivo, o público beneficiado, que recebe e participa igualmente das ações.

No ano de 2015, a Fundação Cultural de Curitiba lançou um edital do tipo "Categoria Livre”, ou seja, esse edital, no valor total de R\$ 2 milhões (dois milhões de reais), que servirá para financiar projetos de todas as áreas, quais sejam: de música; artes cênicas - compreendendo teatro, dança, circo e ópera; audiovisual - cinema, vídeo, internet, televisão e rádio; literatura; artes visuais - fotografia, artes plásticas, design e artes gráficas e tecnológicas; patrimônio histórico, artístico e cultural; folclore, artesanato, cultura popular e demais manifestações culturais tradicionais. Os valores, dentro da verba prevista para o ano, foram destinados na proporção das ofertas e aceites de projetos de cada área. Ou seja, para o ano 
de 2016, o valor de dois milhões de reais é o total investido pela PMC, até o presente momento, por meio de edital, para atender toda a demanda de ações culturais na cidade durante esse ano.

Tal constatação nos remete, novamente, à necessidade de que sejam instituídas Políticas Públicas de Cultura em todos os âmbitos - Municipal, Estadual e Federal - para que programas úteis, urgentes e democráticos como o PCL simplesmente não sejam extintos repentinamente e, ainda, possuam verba própria já destinada às suas ações anualmente definidas.

A recente inclusão do PCL nas ações permanentes da área de Literatura da FCC impedirá que algum administrador público resolva deixar de investir nesse programa, que serve e favorece mais de 30\% (trinta por cento) da população da cidade. A inclusão do PCL no PMC também possibilitará que ele venha a receber incentivos por parte das outras instâncias governamentais, por estar em consonância com o PELLL e PNLLL, em atendimento aos preceitos do PNC.

Os números demonstram grande envolvimento da população com o PCL, o que revela interesse do povo na área da leitura e literatura, contudo sem que o Poder Público ampare projetos de cultura e estabeleça parcerias com a sociedade para executá-los, eles simplesmente não têm condições de prosseguir em andamento e seguem fadados à extinção.

$\mathrm{O}$ administrador público tem prazo de atuação junto à comunidade definido por lei, as políticas públicas não os têm; estas, ao contrário, quando evidentemente benéficas a uma comunidade, devem ter caráter de permanência e continuidade, para que seus benefícios possam, passo a passo, atingir $100 \%$ da população.

A pesquisa ora apresentada discorre sobre o direito humano à leitura, considerado fundamental para o pleno desenvolvimento do ser humano e de suas habilidades em uma sociedade globalizada, em que o grau de informação e de técnica definem as chances que uma pessoa tem de sobreviver com dignidade, igualdade e liberdade no mundo de hoje. $\mathrm{O}$ programa de leitura analisado tem sido eficaz, tanto pelo seu reconhecimento junto ao público quanto pela sua abrangência, num país onde os níveis de alfabetização e de leitura causam tantos danos e prejuízos aos seus cidadãos. Somente viveremos numa sociedade igualitária, justa e 
livre quando todos os cidadãos e povos, indistintamente, tiverem acesso aos bens e aos direitos culturais.

\section{ALGUMAS CONSIDERAÇÕES FINAIS}

Partindo da premissa de que o acesso à cultura e aos seus benefícios é um direito humano fundamental, este trabalho salientou a importância da promoção de Políticas Públicas de Cultura que possibilitem ao povo este acesso.

A tripla função da cultura no mundo contemporâneo - simbólica, cidadã e econômica - impõe ao Poder Público e à sociedade civil dar à cultura a atenção e dimensão que demandam. Ao efetivar o direito fundamental aos direitos e bens culturais se está possibilitando à população o exercício da cidadania e democracia. $\mathrm{O}$ acesso à cultura revela-se atrelado aos demais direitos, tais como: o direito de ir e vir, o direito à educação, o direito à informação, o direito a usufruir dos benefícios da tecnologia, o direito de participar das decisões públicas, o direito ao trabalho, entre outros.

No que diz respeito ao Programa Curitiba Lê, conclui-se que é uma Política Pública eficiente e democrática. O número de cidadãos envolvidos é indicativo dessa afirmação, pois desde a implementação do PCL o quórum de participantes é bastante significativo. Além das atividades descritas nos editais periodicamente publicados e abertos a toda população, as ações do PCL atendem a inúmeras instituições assistenciais, escolas públicas e particulares, lares de idosos, abrigos de menores infratores, enfim: é uma política pública cultural de alta capilaridade dentro do município de Curitiba.

Seu aspecto democrático encontra-se presente desde sua criação, que contou com a participação de todos os segmentos da sociedade, até os dias de hoje, pois os mediadores de leitura e demais participantes do programa são, via de regra, escolhidos dentre cidadãos em geral; o que faz com que haja multiplicidade de estéticas, estilos e gêneros literários dirigidos a todas as camadas da população, indiferentemente de idade, sexo, grau de instrução, patamar econômico entre outras especificidades.

Este estudo, ao buscar ressaltar o aspecto constitucional do acesso aos bens e direitos culturais, teve como escopo, também, dar destaque à 
importância da participação dos municípios no que tange ao desenvolvimento cultural do país. Os Estados, por sua vez, devem proporcionar meios e estabelecer diretrizes culturais de acordo com as peculiaridades da região em que se encontram, em respeito às distintas e incontáveis tradições e características regionais presentes no Brasil.

O Plano Nacional do Livro e da Leitura proporciona aos Estados e Municípios a oportunidade de, em alinhamento conjunto, desenvolverem programas e sistemas de cultura, no sentido de incrementar, aparelhar e instrumentalizar o acesso à cultura, mediante a formação de agentes e gestores culturais, criação de órgãos, conselhos, espaços culturais e demais aparatos necessários para atender essa área fundamental para o desenvolvimento do país.

Com a certeza de que o domínio da leitura é um dos meios imprescindíveis para que um cidadão tenha acesso a todos os direitos e benefícios discorridos ao longo deste estudo de políticas públicas de cultura, conclui-se este artigo crendo na necessidade de implementação de condições igualitárias, democráticas e cidadãs de existência aos brasileiros, indistintamente; uma vez que para que estes tenham acesso à cultura, a transversalidade inerente a ela deve ser reconhecida; sendo os meios para supri-la providenciados; e, em obediência ao que preceitua a $\mathrm{CF} / 88$, proporcionar ao povo brasileiro condições de vida de acordo com o princípio da dignidade humana, da igualdade e da liberdade.

\section{REFERÊNCIAS}

BATTINI. Odária. A criança e o adolescente em questão: construindo uma metodologia de trabalho. Londrina: UEL, 1993.

BRASIL. Ministério da Cultura. Caderno do PNLL. 2014. Disponível em: <http://www.cultura.gov.br/documents/10883/1171222/cadernoPNLL 20 14ab.pdf/df8f8f20-d613-49aa-94f5-edebf1a7a660>. Acesso em: 26 jul. 2015 .

MEYER-BISCH, Patrice; BIDAULT, Mylène (Org.). Afirmar os direitos culturais: comentário à declaração de Friburg. Trad. de Ana Goldberg. São Paulo: Iluminuras, 2014.

CANDIDO, Antonio. O direito à literatura. In: CANDIDO, Antonio. Vários escritos. 4. ed. Rio de Janeiro: Ouro Sobre Azul, 2012.

COELHO, Teixeira (Org.). A Cultura pelas cidades. São Paulo: Iluminuras; Itaú Cultural, 2008. 
COELHO, Teixeira. Dicionário crítico de política cultural: cultura e imaginário. 2. ed. (rev. e ampliada). São Paulo: Iluminuras, 2012.

CUNHA FILHO, Francisco Humberto. Direitos culturais como direitos fundamentais no ordenamento jurídico brasileiro. Brasília: Brasília Jurídica, 2000.

FAILLA, Zoara (Org.). Retratos da leitura no Brasil. São Paulo: Imprensa Oficial; Instituto Pró-livro, 2012.

GARGARELLA, Roberto. Constitución y Democracia. In: ALBANESE, Susana; DALLA VIA, Alberto; GARGARELLA, Roberto; HERNÁNDEZ, Antonio; SABSAY, Daniel (Orgs). Derecho constitucional. Buenos Aires: Universidad, 2004.

GARGARELLA, Roberto. Los fundamentos legales de la desigualdad - el constitucionalismo en América (1776-1860). Buenos Aires: Siglo XXI, 2008.

HABERMAS, Jürgen. Direito e democracia: entre facticidade e validade. v. I. Trad. Flávio Beno Siebeneichler. Rio de Janeiro: Tempo Brasileiro, 2003.

HABERMAS, Jürgen. A inclusão do outro: estudos de teoria política. Trad. George Sperber, Paulo Astor Soethe e Milton Camargo Mota. São Paulo: Loyola, 2004.

LANDRY, Charles; BIANCHINI, Franco. The Creative City. London: Demos, 1995.

LANDRY, Charles. The Creative City: A Toolkit for Urban Innovators. 2. ed. London: Comedia, 2008.

MARQUES NETO, José Castilho. Plano Nacional do Livro e Leitura: os primeiros quatro anos e o futuro. In: MARQUES NETO, José Castilho (Org.). PNLL: textos e história. São Paulo: Cultura Acadêmica, 2010.

MEDEIROS, Claudia Lucio; SILVA, Daniela. Direitos culturais e efetivação das políticas públicas. Disponível em:

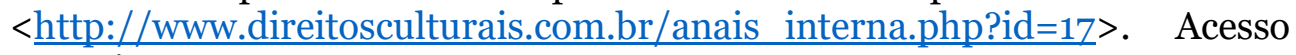
em: 2 jun. 2015.

NINO, Carlos Santiago. La constitución de la democracia deliberativa. Barcelona: Gedisa, 1999.

NINO, Carlos Santiago. Fundamentos de derecho constitucional - análisis filosófico, jurídico y politológico de la práctica constitucional. Buenos Aires: Astrea, 2005.

RUBIM, Antonio Albino Canelas; BARBALHO, Alexandre (Org.). Políticas culturais no Brasil. Salvador, EDUFBA, 2007.

RUBIM, Antonio Albino Canelas. Políticas culturais: entre o possível \& o impossível. In: NUSSBAUMER, Gisele Marchiori (Org.). Teorias e políticas da cultura: visões multidisciplinares. Salvador: EDUFBA, 2007. p. 139-158.

SCHWARTZ, Germano. A constituição, a literatura e o direito. Porto Alegre: Livraria do Advogado, 2006.

SEBRAE SP. Políticas públicas municipais de apoio às micro e pequenas empresas. In: CALDAS, Ricardo W.; CRESTANA, Silvério (Org.). São Paulo: SEBRAE, 2005. 
SHAHEED, Farida. O novo papel dos direitos culturais. Entrevista concedida por Farida Shaheed para Teixeira Coelho. Revista Observatório Itaú Cultural, São Paulo, n. 11, p. 15-26, jan./abr. 2011. Disponível em: $<$ http://www.itaucultural.org.br/bcodemidias/001813.pdf $>$. Acesso em: 1 jun. 2015 .

SOUZA NETO, Cláudio Pereira de. Teoria constitucional e democracia deliberativa: um estudo sobre o papel do Direito na garantia das condições para a cooperação na deliberação democrática. Rio de Janeiro: Renovar, 2006.

\section{ANEXO 1 - LISTA DE ABREVIATURAS}

AMAFEMO - Associação de Moradores das Vilas São Fernando e Santa Mônica

CAIC - Centro de Atenção Integral à Criança e ao Adolescente

CAPS - Centro de Atenção Psicossocial

CATI - Centro de Atividade da Pessoa Idosa

CBL - Câmara Brasileira do Livro

CEEBJA - Centro Estadual de Educação Básica para Jovens e Adultos

CEI - Centro Profissionalizante

CF/88 - Constituição da República Federativa do Brasil de 1988

$\mathrm{CF}$ - Constituição Federal

CMAE - Centro Municipal de Atendimento Especializado

CMEI - Centros Municipais de Educação Infantil

COHAB - Companhia de Habitação Popular de Curitiba

COHABPR - Companhia de Habitação Popular do Paraná

CRAS - Centro de Referência da Assistência Social

CREAS - Centro de Referência Especializada da Assistência Social

FAS - Fundação da Ação Social

FCC - Fundação Cultural de Curitiba

FCRB - Fundação Casa de Rui Barbosa

FMC - Fundo Municipal de Cultura

FUNARTE - Fundação Nacional da Arte

FUNASA - Fundação Nacional da Saúde

FUNDACEN - Fundação Nacional de Artes Cênicas

IBAC - Instituto Brasileiro de Arte e Cultura

IBGE - Instituto Brasileiro de Geografia e Estatística

ICAC - Instituto Curitiba de Arte e Cultura

IMAP - Instituto Municipal de Administração Pública

INAF - Indicador Nacional de Alfabetismo Funcional

INL - Instituto Nacional do Livro 
IPHAN - Instituto do Patrimônio Histórico e Artístico Nacional

IPPUC - Instituto de Pesquisa e Planejamento Urbano de Curitiba

MEC - Ministério da Educação

MinC - Ministério da Cultura

NRE - Núcleos Regionais da Educação

OEI - Organização dos Estados Ibero-americanos

OECD - Organização para a Cooperação e Desenvolvimento Econômico

ONG - Organização Não Governamental

OSC - Organização da Sociedade Civil

PCL - Programa Curitiba Lê

PELLL - Plano Estadual do Livro, Leitura e Literatura do Paraná

PIDESC - Pacto Internacional dos Direitos Econômicos, Sociais e Culturais

PMC - Prefeitura Municipal de Curitiba

PMLLL - Plano Municipal do Livro, Leitura e Literatura de Curitiba

PMPR - Policia Militar do Paraná

PNLL- Plano Nacional do Livro e da Leitura

SBB - Sociedade Bíblica do Brasil

SEED - Secretaria da Educação do Paraná

SENAC - Serviço Nacional de Aprendizagem Comercial

SESA - Secretaria Estadual da Saúde

SESI - Serviço Social da Industria

SME - Secretaria Municipal de Educação

SMELJ - Secretaria Municipal de Esporte, Lazer e Juventude

SMS - Secretaria Municipal da Saúde

UAI - Unidade de Acolhimento Institucional

UEI - Unidade de Educação Integral

UNESCO - Organização das Nações Unidas para Educação, Ciência e Cultura

Idioma original: Português

Recebido: 08/09/18

Aceito: 14/11/18 